\title{
Cork: properties, capabilities and applications
}

\author{
S. P. Silva ${ }^{1,2}$, M. A. Sabino ${ }^{1,2}$, E. M. Fernandes ${ }^{2}$, V. M. Correlo $^{2}$, L. F. Boesel ${ }^{2}$ \\ and R. L. Reis ${ }^{* 1,2}$
}

Cork is a natural, renewable, sustainable raw material that has been used for many centuries. As a result of this very long term interest, the scientific literature on cork is extensive. The present review focuses on the chemical composition, physical and mechanical properties of cork and on its products and sub-products. The substantial efforts to fully characterise cork, as well as new developments and evolving research, are reviewed, beginning with its histology, growth and morphology (at macro- and microscales). The chemical structure is analysed in detail, covering both the materials that form the wall structure and the low molecular weight, extractable components. The unique properties of cork are discussed and correlated with current knowledge on morphology and chemical structure. Finally, the important industrial applications of cork are reviewed, in the context of research to provide cork with novel, high added-value applications.

Keywords: Cork, Mechanical properties, Chemical composition, Applications, Morphology

\section{Introduction}

Cork is the bark of the oak (Quercus suber L.) which is periodically harvested from the tree, usually every 9-12 years, depending on the culture region. Quercus suber $L$. is the botanical name for a slow growing, evergreen oak that flourishes only in specific regions of the Western Mediterranean (Portugal, Spain, Southern France, part of Italy, North Africa) and China. ${ }^{1-7}$ This tree requires a great deal of sunlight and a highly unusual combination of low rainfall and somewhat high humidity. Europe has about $60 \%$ of the total production area (cork forests) and produces more than $80 \%$ of the world's cork. ${ }^{2}$ Portugal is the major cork producer and processes about three-quarters of all the cork. The quality and thickness of the bark vary according to a tree's specific growth conditions. ${ }^{3,7}$

\section{Morphology}

The cork tree has a remarkable capacity to create suberose tissue from its inner bark. This tissue, formed specifically by the phellogen of the cork oak (the tissue responsible for the formation of new cells), derives its name from the Latin suber (=cork). The life cycle of the cork oak produces three qualities of suberose tissue: virgin cork; reproduction cork from the second stripping; and reproduction cork from subsequent strips. ${ }^{2}$ The thickest suberose layer is generally formed in the growing cycle following cork extraction, after which the

${ }^{1}$ Corticeira AMORIM SGPS, DNAPC-Departamento de Desenvolvimento de Novas aplicações/produtos em/com cortiça, Apartado 13, Rua de Ribeirinho N ${ }^{\circ}$ 202, 4536-907 S Paio dos Oleiros Codex, Portugal

23B's Research Group-Biomaterials, Biodegradables and Biomimetics, Department of Polymer Engineering, University of Minho, Campus de Azurém, 4800-058 Guimarães, Portugal

*Corresponding author, e-mail ruireis@ corticeira.amorim.com cork produced per year diminishes progressively until the next extraction. ${ }^{1,4-6}$

\section{Histology and cytology}

Cork (or phellem, the botanical designation of this vegetable tissue) is a protective layer of suberised dead cells, formed from phellogen tissue. The phellogen has meristematic (cell generation) capacity. After cellular division, the new cells do not have their final dimensions and subsequently undergo growth in the protoplasm (cellular interior); in this way phellogenic tissue continues to thicken and the tree perimeter increases. Tissue growth ceases in winter and starts again at the beginning of the spring. The phellogenium period is AprilOctober; the winter standstill is manifested in highly visible dark zones, marking off the phellem produced each year (Fig. 1). The annual addition of phellogenic layers corresponding to lenticular evolution, determines the definition of lenticular channels (radial and oriented pores) where the oxygenation of meristematic tissue takes place. ${ }^{7,8}$ The main function of meristematic tissue is mitosis (cellular division); these cells are small, thinwalled and with no specialised features. Cork acts as a barrier between the atmosphere and the cortex of the stem, and lenticels serve as mass transfer channels for water and gases. ${ }^{9}$ The phellogenic tissue of cork oak is active throughout the tree's life. ${ }^{2}$

The cell membranes formed are very thin, devoid of lines of communication from cell to cell, and are mostly formed by suberin, lignin and cellulose. ${ }^{10-13}$ Internally, cells contain cerin crystals and fridelin, as well as amorphous material and a large quantity of gas or air that is not expelled by the compression of the tissue (Fig. 2). ${ }^{1}$

The effects of cork removal on the tree include increased water loss from the exposed surface, which may induce a decrease in stomatal activity ${ }^{4,7,9}$ (reducing the biological activity of the tree) and the death of the 


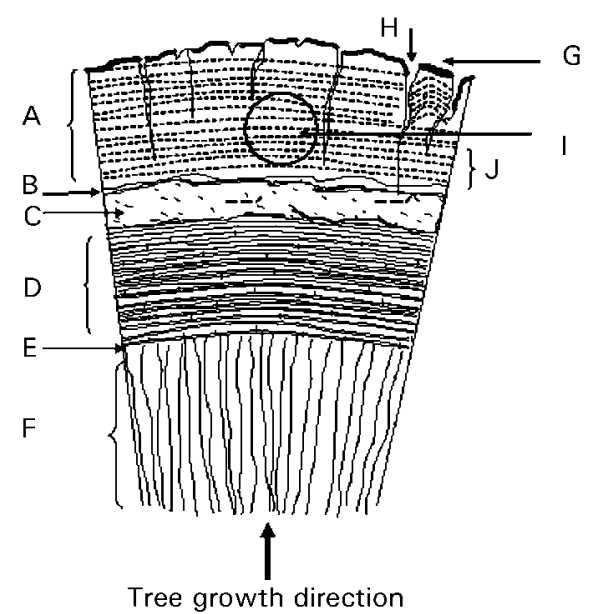

1 Schematic representation of axial section of cork oak tree; (A) cork (suberose tissue), (B) subero-phellogenic change, (C) phellogenium, (D) liber tissue, (E) liberwood change, (F) wood, (G) bark, (H) lenticular channels, (I) area for stopper production, (J) annual growth rings

newly exposed inner bark tissues with subsequent formation of a traumatic periderm starting approximately 30 days after cork extraction. Tree growth (wood) is also affected by cork extraction with a considerable decrease in ring width and a disturbed anatomy. 5,14

In cork oak, radial and axial growth starts simultaneously in early spring. Leaf flushing occurs at the beginning of spring and again in autumn if the environmental conditions allow it. ${ }^{15-17}$ Cork extraction is done when growth is highest (summer), when the phellogen is in full meristematic activity allowing easy separation of the cork layers.

\section{Macroscopic morphology}

The natural cork bark passes through several selections and manipulations. After collection, the first step is to put the planks in water vapour. This relaxes the cork cell walls and so allows straightening of the bent planks.

Cork intended for stoppers is visually inspected and selected to guarantee the best appearance and properties. After extraction from these planks, the stoppers are further manually or automatically selected. Stoppers for top quality wines undergo another, finer selection. Selection is essentially based on external surface analysis. $^{18,19}$

Cork trees are harvested, every 9 or 10 years (Fig. 3), after they reach $25 \mathrm{~cm}$ in diameter. After the harvest, the trees will be left to re-grow their bark, which takes about another 9 years. There is a significant difference between the first harvest, and the third and successive harvests. ${ }^{1,4,7,20}$

Virgin cork is irregular in structure, thickness and density, and is hard-rough; it is crumbly and can be used only for cork board, insulation, gaskets, shoe soles, etc. $^{21}$

First reproduction cork (taken at least 9 years later) is more regular than virgin, but is of insufficient quality for cork stoppers. ${ }^{5}$ By this harvest, the cork has a smooth, unblemished bark. The best quality reproduction cork is termed 'amadia', 6,22 Only second reproduction cork is

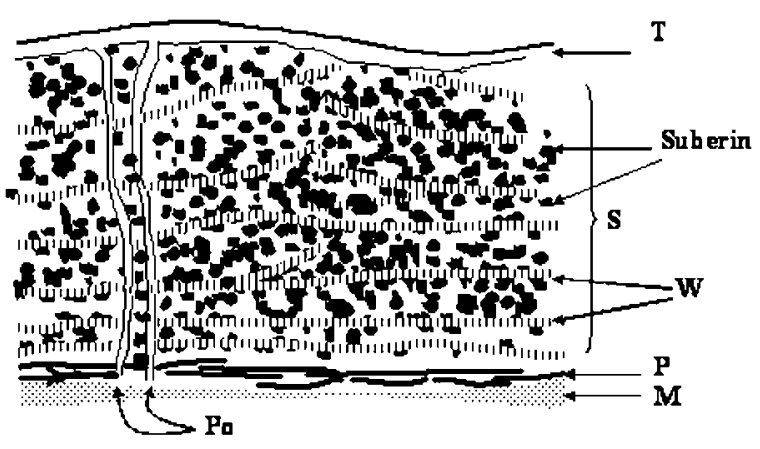

2 Structure of cork oak cell wall (Sitte model ${ }^{178}$ ); (T) tertiary wall, (S) secondary wall, (W) waxes and suberin, $(\mathrm{P})$ primary wall, $(\mathrm{M})$ medium lamella, $(\mathrm{Po})$ pore

used for cork stopper production, while all types of cork can be used for agglomerates.

The quality of cork is carefully monitored from field production to industrial processing ${ }^{23}$ and is critical in determining adequacy for stopper production and the economic value of cork planks and end products. $1,6,22$ All cork must be boiled before working to make it more pliable, and to fully expand the lenticels. Initially, the cork cells are collapsed and wrinkled, but after boiling (for about $1 \mathrm{~h}$ ), the interior gas in the cells expands to create a very tight, uniform cell structure, ${ }^{6,21}$ as described below.

Once the boiled, expanded, flat cork has dried to $20 \%$ moisture content, it is ready to be worked. To achieve the quality demanded by winemakers, ${ }^{21}$ the corkwood must have very few defects and be consistent in colour, texture and thickness (Fig. 4). ${ }^{19}$ Most of the sorting is done by hand into classes according to quality, thickness and size. ${ }^{5}$

\section{Microscopic morphology}

The cellular structure of cork is well known ${ }^{6,15,24-26}$ and cork tissue has retained a special place in the history of plant anatomy. Hooke ${ }^{1}$ was the first to examine thin

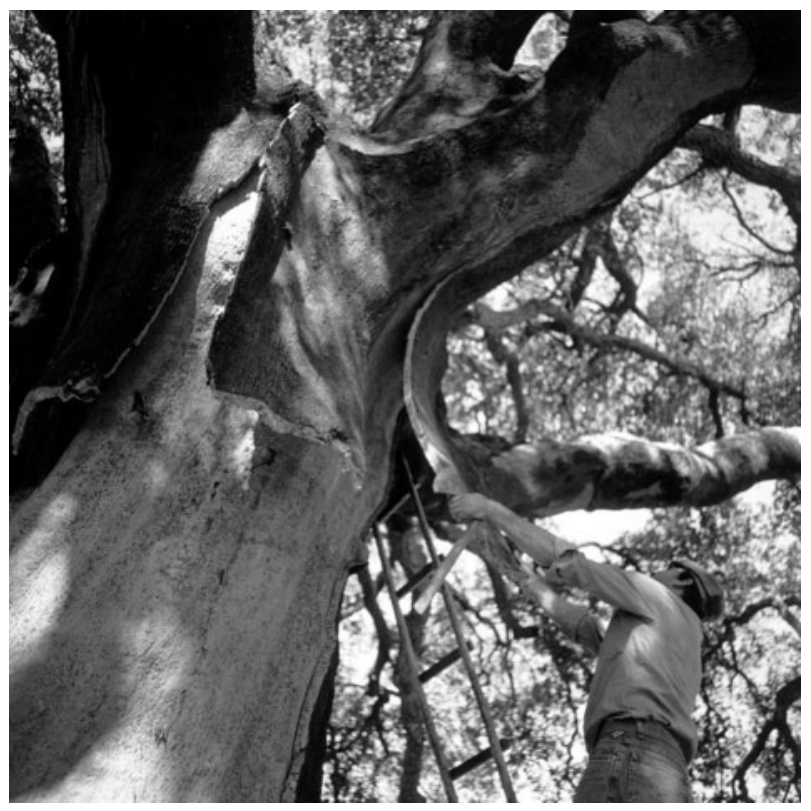

3 Debarking process [copyright Associação Portuguesa da Cortiça (APCOR), 2002] 


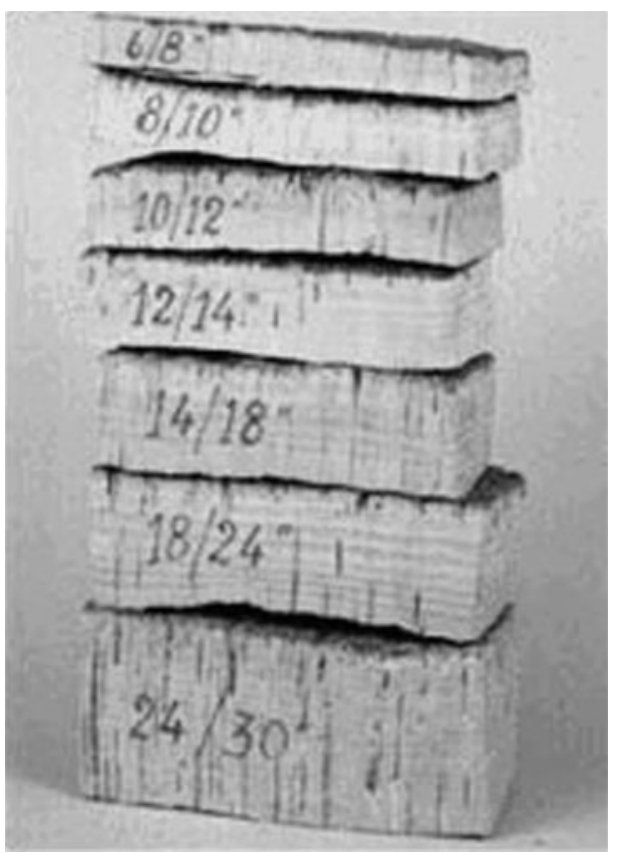

4 Qualitative classification of reproduction 'amadia' as a function of cork plank thickness or calibre (expressed as 'linhas') after boiling; one 'linha' corresponds to $2.25 \times 10^{-2} \mathrm{~m}$

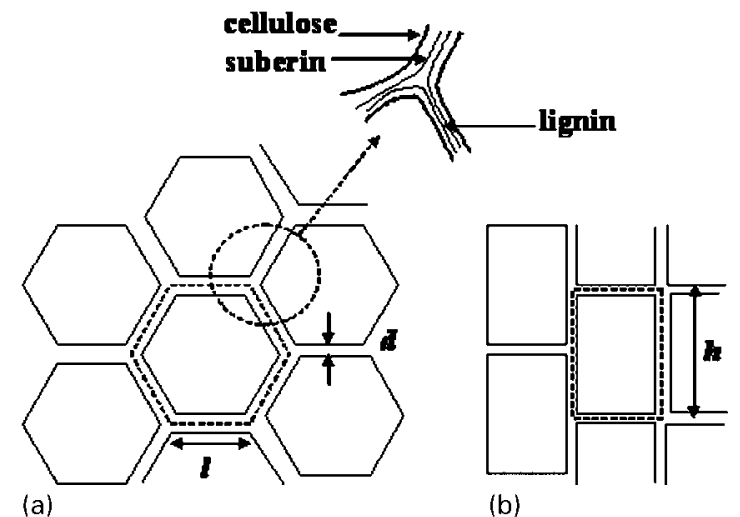

5 Schematic representation of cork cells; a radial section: l, prism base edge; $d$, wall thickness; $b$ tangential/axial section (perpendicular to radial direction): $h$, prism height; detail of cellular structure walls of cork showing its main components

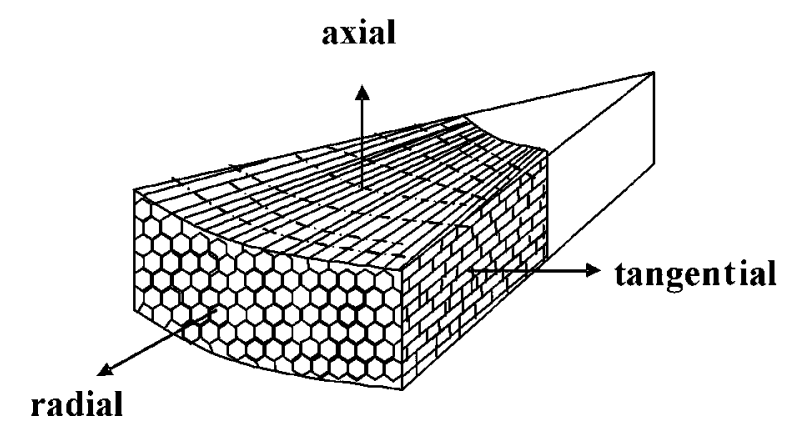

6 Schematic representation of cellular disposition in cork growing section; arrows indicate names of the three sections and corresponding directions in cork planks
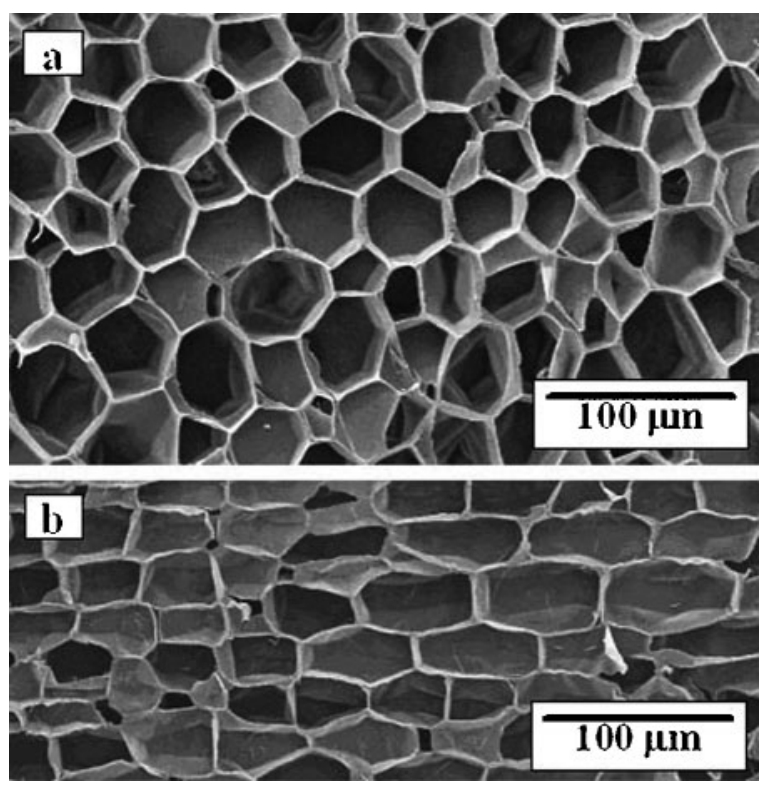

$a$ radial section; $b$ tangential section

7 SEM micrograph of natural cork (after boiling)

sections of cork under the microscope and reveal its cellular structure. ${ }^{1,20}$ Cork was observed by scanning electron microscopy (SEM) ${ }^{6}$ for the first time in 1987.

Cork may be described as a homogeneous tissue of thin-walled cells, regularly arranged without intercellular space. Cork reveals an alveolar structure, analogous to that of a honeycomb, ${ }^{26}$ with no empty spaces between contiguous cells, which are therefore closed units $^{4,6,15,24,25}$ (Figs. 5 and 6). Because the lateral cell walls (parallel to the radial direction) are randomly oriented, cork can be considered, in a first approximation, as a transversally isotropic material, implying that all directions perpendicular to the radial direction (i.e. the axial and tangential directions) are nearly equivalent. ${ }^{1,27}$

The cells can be described as rectangular prisms, packed base-to-base in columns parallel to the radial direction of the tree (Fig. 6). The minuscule alveoli are compactly arranged, and their dimensions are so minute that the number of cells can vary significantly from cork to $\operatorname{cork}^{4}$ (Table 1). Cork always contains lenticular channels, which run radially. These channels are approximately cylindrical and therefore do not destroy the cylindrical symmetry in the radial direction. The lenticular channels are usually hollow; their volume fraction varies considerably with cork type and is closely related to its industrial quality. ${ }^{15,25}$

SEM observation of cork showed that, in a radial section, cork cells appear as 4- to 9-sided polygons (Fig. 7a) (heptagonal, hexagonal and pentagonal cells are the most frequent statistically). ${ }^{4,6}$ Three cell walls

Table 1 Cell dimensions of cork cells during different growing periods ${ }^{6}$

\begin{tabular}{lll}
\hline Cell dimensions & Early cork & Late cork \\
\hline Prism height, $\mu \mathrm{m}$ & $30-40$ & $\sim 10$ \\
Prism base edge, $\mu \mathrm{m}$ & $13-15$ & \\
Average base, $\mathrm{cm}^{2}$ & $4-6 \times 10^{-6}$ & \\
Wall thickness, $\mu \mathrm{m}$ & $1-1.5$ & $\sim 2$ \\
Number of cells $/ \mathrm{cm}^{3}$ & $4-7 \times 10^{7}$ & $10-20 \times 10^{7}$ \\
\hline
\end{tabular}




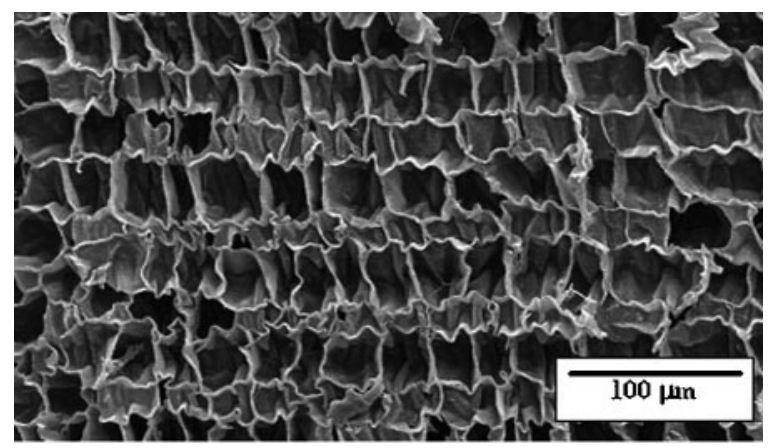

8 SEM micrographs of tangential section showing corrugations of natural cork cells walls (after boiling)

meet at each vertex of the network and triangular forms are very rare. ${ }^{4,15,25,27}$

Axial and tangential sections show a structure that resembles a brick wall (Fig. $7 b$ ). Again, generally three edges meet at each vertex, although occasionally meetings of four edges are observed. The cells are arranged in rows parallel to the radial direction. In spite of the rectangular appearance, topologically the number of sides (and vertices) is not always four; in fact, the average number of sides reported is six. ${ }^{27}$

To ensure that these micrographs are representative of the real morphology of cork cells (i.e. that the cells in Figs. 7 and 8 have not been artificially expanded by internal gas pressure in the low-pressure SEM), the present authors have performed similar observations in an environmental SEM (ESEM) apparatus, at pressures much higher than those employed in conventional SEM. The morphology of cork was exactly the same, as were the dimensions of the cells. Moreover, the cork cells have rigid walls with an estimated ${ }^{28}$ compressive modulus of $\sim 9 \mathrm{GPa}$, a value high enough to avoid such artificial expansion.

An important characteristic of prismatic cork cells is that their lateral faces are corrugated (Fig. 8), with two or three complete corrugations per cell. ${ }^{24,29}$ This corrugation can be irregular: the walls of cells range from almost straight to heavily corrugated, and some are even collapsed. The bases of cork cells are also undulated, but complete corrugations are not generally reported. These corrugations of the lateral cell walls probably result from compression during cell and bark growth. $^{21,25,29,30}$

During the different periods of cork tree growth, the cells are heavily corrugated and, at the beginning of the growth layer, collapse against the last cells produced in the previous growing season. These late cork cells, with their thicker cell walls and reduced prism height, show much less corrugation and are likely to be more rigid. Therefore, the average dimensions of cork cells depend appreciably on the season in which they were formed. These values are outlined in Table 1 .

The anisotropy of cork's cellular structure implies that its properties will also be anisotropic. ${ }^{24}$ Cork cells are closed and hollow, containing in their interior a gas, presumably similar to air, that plays an important role in their properties. Cork's structure leads to a very low specific weight; it lengthens easily under stress and shortens when compressed, ${ }^{30}$ inducing the characteristic mechanical properties ${ }^{10}$ discussed below.

\section{Density}

The density of cork can vary within wide limits, depending mostly on its age (virgin or reproduction) and treatment (natural or boiled). ${ }^{21}$ Density can vary by as much as a factor of $2\left(120-240 \mathrm{~kg} \mathrm{~m}^{-3}\right)$. The factors that affect density have been widely discussed. ${ }^{29}$ Since the density of the cell wall materials is believed to be fairly constant, the global density variations must be related to the cell dimensions (height and wall thickness), cell wall corrugation, and/or the volume fraction of lenticular channels. High densities correspond to thick and heavily corrugated walls and a low incidence of lenticular channels. ${ }^{21,24,29,30}$

Variations of density within a cork board are expected, in view of the variations of cell wall thickness and corrugations within a growth ring. Boiling cork reduces the corrugation of the cells walls, leading to a decrease in density. ${ }^{5,24,29}$ An increase of approximately $10-15 \%$ is observed in the radial direction and $5-7 \%$ in the axial and tangential directions, i.e. $\sim 30 \%$ volume increase. $^{21,25}$

The macroscopic porosity of cork, the main indicator of quality, corresponds to the prevalence of lenticular channels that cross cork planks radially. ${ }^{14,16,17}$ There is a large variation of porosity between different trees, as well as in early and late cork. The total porosity of the cork plank decreases by approximately half as a consequence of the boiling process, the expansion during boiling inducing the formation of larger pores. ${ }^{21}$ The technological quality of cork planks is generally improved by boiling, owing to the higher uniformity induced, allowing them to be flattened and improving their workability. ${ }^{13,19}$

Cells formed during spring are taller, with thinner walls; therefore autumn cells are denser. Thin planks are denser than thicker ones, owing to their lower porosity, lower number of cells per annual growth ring and lower cell prism height. ${ }^{27}$ The volume fraction of lenticular channels ${ }^{29,31}$ can influence density by a factor of $1 \cdot 4$. The density of the cell walls had been estimated ${ }^{24}$ as $1200 \mathrm{~kg} \mathrm{~m}^{-3}$ on the basis of their chemical composition.

\section{Chemical composition}

The chemical constitution of cork has been widely examined $^{1,10,11,13,20,24,32-36}$ and found to depend on factors such as geographic origin, climate and soil conditions, genetic origin, tree dimensions, age (virgin or reproduction) and growth conditions. Cork from Quercus suber $L$. has peculiar properties such as high elasticity and low permeability; these result, at least partially, from its specific chemical composition (and more especially from that of suberin). ${ }^{20,32,34-36}$

The cellular structure of cork wall consists of a thin, lignin rich middle lamella (internal primary wall), a thick secondary wall made up from alternating suberin and wax lamella and a thin tertiary wall of polysaccharides (Figs. 2 and 5). Some studies suggest that the secondary wall is lignified and therefore may not consist exclusively of suberin and waxes. ${ }^{37}$ Of these cell wall components, suberin is the most abundant (approximately 40\%), lignin corresponds to $22 \%$, polysaccharides to $18 \%$ and extractables to $15 \% .^{20,32,34-37}$

Table 2 summarises the compositions reported in the literature. $^{1,10,13,35,38}$ It can be seen that there are 


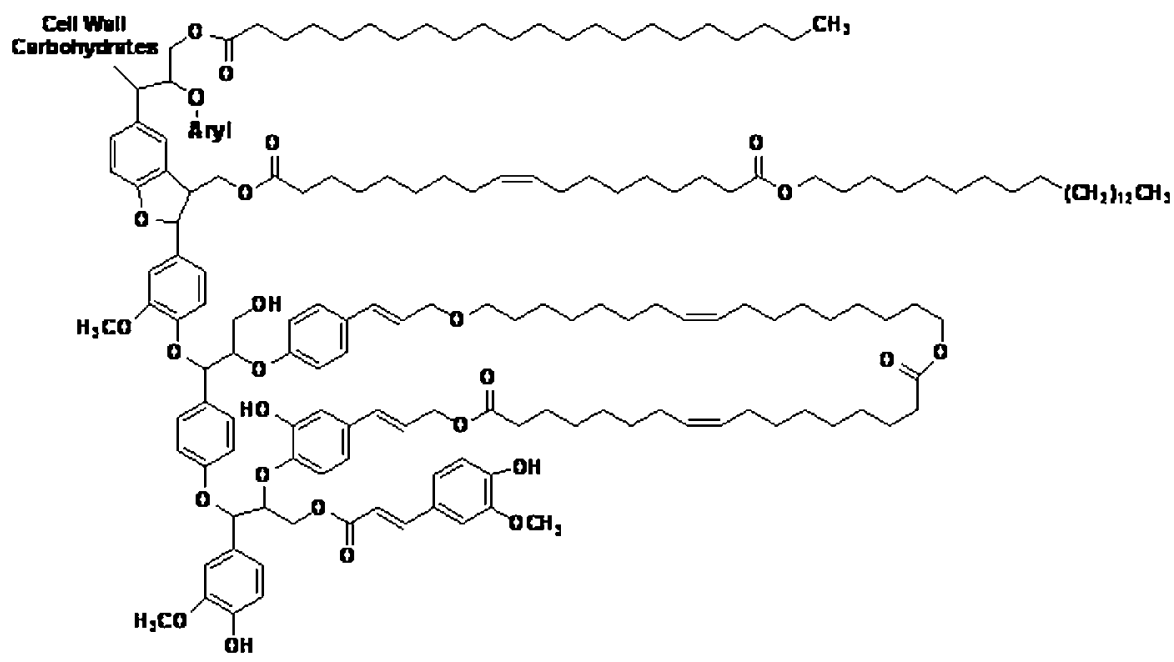

9 Schematic structure proposed for cork suberin

differences in composition associated with cork formation. Virgin cork contains, on average, more suberin than cork regenerated after the initial extraction. The virgin cork also has a higher extractable content (more waxes and fats). ${ }^{35}$ The question thus arises of the role of suberin and waxes in the cork cell wall and the factors influencing their biogenesis. ${ }^{39}$

The decrease in suberin and wax content in regenerated cork may be related to a decrease in the thickness of the secondary wall, since these components comprise alternate layers in the secondary wall of cork cells. ${ }^{35,40}$ More research will be necessary to confirm this hypothesis. It should also be noted that the reproduction samples studied were obtained from trees on which the number of cork extractions already made was not known; very probably, the number differed from sample to sample. A relation between chemical composition and number of cork extractions might therefore explain the variations observed. Soil and climate conditions will also influence the biogenesis of the individual cork components and further studies on trees grown in different environments are recommended. ${ }^{35,40,41}$

\section{Suberin}

The structure of suberin in cork is not yet fully understood. It has been proposed that suberin consists of a polyester structure composed of long chain fatty acids, hydroxy fatty and phenolic acids, linked by ester groups. ${ }^{32,35-40}$ To date, only a model of the suberin chemical structure has been proposed in the literature. $^{36,39}$ The precursors for suberin and the proposed structure are shown in Tables 3, 4 and Fig. 9.

Several wet chemical techniques (alkaline hydrolysis, alcoholysis, trans-esterification/reduction) have been used to depolymerise suberin by cleavage of the ester bonds, for analysis of its monomeric subunits. ${ }^{32,34} 40$ Some workers ${ }^{11,37,38}$ have detected the cork suberin ester and/or ether monomers (e.g. alkanoic acids $3 \cdot 3 \% ; \alpha, \bar{\omega}$ diacids $10 \cdot 1 \%$; $\bar{\omega}$-hydroxyacids $48 \cdot 1 \%$; alkanols $1 \cdot 8 \%$; 9,10-epoxy-18-hydroxyoctadecanoic acid 5.8\%; 9,10epoxyoctadecanodioic acid $3 \cdot 6 \% ; 9,10,18$-trihydroxyoctadecanoic acid, 10.4\%; 9,10-dihydroxyoctadecanedioic $6.8 \%$; ferulic acid $4 \cdot 5 \%$ and glycerol $14 \cdot 3 \%$ ). More recently, other techniques, ${ }^{11,37}$ e.g. thermally assisted trans-methylation using gas chromatography-mass spectrometry (GC-MS), Fourier transformed IR spectroscopy (FTIR) and solid state nuclear magnetic resonance $\left({ }^{13} \mathrm{C}-\mathrm{NMR}\right)$, have been used to characterise aliphatic and phenolic suberin precursors; the results are in agreement with those reported previously. ${ }^{42,43}$ On the basis of this information, an improved model is proposed in this study for the suberin structure (Fig. 9).

If it is accepted that suberose tissue contains both poly(aliphatic) and poly(phenolic) domains, and that the latter is not lignin, then the term suberin must be used judiciously and specifically in reference to a macromolecule containing both, as is the case in cork. ${ }^{36,39}$

Enzymatic methods ${ }^{44}$ have been used to isolate polymeric suberin from the bark of Quercus suber $L$.

Table 2 Differences in results of quantitative analysis of cork chemical composition

\begin{tabular}{|c|c|c|c|c|c|c|c|c|}
\hline \multirow[b]{2}{*}{ Component } & \multicolumn{2}{|c|}{ Virgin cork } & \multicolumn{6}{|c|}{ Reproduction cork (amadia) } \\
\hline & $\begin{array}{l}\text { Caldas } \\
(1986)^{13}\end{array}$ & $\begin{array}{l}\text { Pereira } \\
(1981)^{35}\end{array}$ & $\begin{array}{l}\text { Gil } \\
(1998)^{1}\end{array}$ & $\begin{array}{l}\text { Caldas } \\
(1986)^{13}\end{array}$ & $\begin{array}{l}\text { Pereira } \\
(1981)^{35}\end{array}$ & $\begin{array}{l}\text { Parameswaran } \\
(1981)^{13 *}\end{array}$ & $\begin{array}{l}\text { Holloway } \\
(1972)^{38}\end{array}$ & $\begin{array}{l}\text { Carvalho } \\
(1968)^{13 *}\end{array}$ \\
\hline Suberin & 45 & 45 & 42 & 48 & 33.5 & 33 & 37 & 50 \\
\hline Lignin & 27 & 21 & $21 \cdot 5$ & 29 & 26 & 13 & $14 \cdot 8$ & 19 \\
\hline $\begin{array}{l}\text { Polysaccharides } \\
\text { (cellulose and hemicellulose) }\end{array}$ & 12 & 13 & 16 & 12 & 25 & 6 & & 13 \\
\hline Extractables & 10 & 19 & 13 & $8 \cdot 5$ & 13 & 24 & $15 \cdot 8$ & 15 \\
\hline Ash & 5 & $1 \cdot 2$ & & $2 \cdot 1$ & 2.5 & $\ldots$ & & 3 \\
\hline Others & $\ldots$ & 0.8 & 7 & $\ldots$ & $\ldots$ & 6 & $\ldots$ & $\ldots$ \\
\hline
\end{tabular}

*Referenced by Caldas et al. ${ }^{13}$ 
(a)<smiles>CCCCCCCCCCCCCCCCCCCO</smiles><smiles>CCCCCCCCCCCCCCCCCCCC(=O)[O-]</smiles><smiles>O=C(O)CCCCCCCCCCCCCCCCCCO</smiles><smiles>O=C([O-])CCCCCCCCCCCCCCCCCCC(=O)O</smiles><smiles>O=C([O-])CCCCCCCCCC(O)CCCCCCCCO</smiles><smiles>CCCCCCCCC(O)C(O)CCCCCCCCCC(=O)[O-]</smiles><smiles>O=C([O-])CCCCCCCCCC(O)C(O)CCCCCCCO</smiles><smiles>O=C([O-])CCCCCCCCCC(O)C(O)CCCCCCCC(=O)[O-]</smiles><smiles>O=C([O-])CCCCCCCC1OC1CCCCCCCCO</smiles><smiles>O=C([O-])CCCCCCCCC1OC1CCCCCCCC(=O)[O-]</smiles><smiles>CCCCCCCCCCCCCCCCCCOC(=O)/C=C/c1ccc(O)c(OC)c1</smiles>

(b)<smiles>OCC(O)CO</smiles>

Alkanoic acids

$\omega$-Hydroxyalkanoic acids

$\alpha, \omega$-Alkandioic acids

9(10), $\omega$-Dihydroxyalkanoic acid

9(10)-Dihydroxyalkanoic acid

9,10,18-Trihydroxyalkanoic acid

9,10-Dihydroxy- $\alpha, \omega$-alkanoic acid

9,10-Epoxy- $\omega$-hydroxyalkanoic acid

9,10-Epoxy- $\alpha, \omega$-alkandioic acid

Ferulates

an average molecular weight of $2050 \mathrm{~g} \mathrm{~mol}^{-1}$. Although this fraction represents only $10 \%$ of the whole suberin of cork, its polymeric nature gives valuable information about the native form of the polymer.

Few thermal characterisation studies of suberin have been conducted. Using polarised light microscopy with heating and cooling procedures, Cordeiro and coworkers $^{45,46}$ observed a typical birefringence image at room temperature of a suberin sample (obtained by an 
<smiles>[R]c1cc(/C=C/C(=O)[O-])cc([R])c1O</smiles>

$\mathrm{R}_{1}=\mathrm{R}_{2}=\mathrm{H}, p$-Coumaric acid

$\mathrm{R}_{1}=\mathrm{OH}, \mathrm{R}_{2}=\mathrm{H}$, Caffeic acid

$\mathrm{R}_{1}=\mathrm{OCH}_{3}, \mathrm{R}_{2}=\mathrm{H}$, Ferulic acid

$\mathrm{R}_{1}=\mathrm{R}_{2}=\mathrm{OCH}_{3}$, Sinapic acid<smiles>[R]c1cc(/C=C/CCO)cc([R])c1O</smiles>

$\mathrm{R}_{1}=\mathrm{R}_{2}=\mathrm{H}, p$-Coumaryl alcohol

$\mathrm{R}_{1}=\mathrm{OCH}_{3}, \mathrm{R}_{2}=\mathrm{H}$, Coniferyl alcohol

$\mathrm{R}_{1}=\mathrm{R}_{2}=\mathrm{OCH}_{3}$, Synapyl alcohol

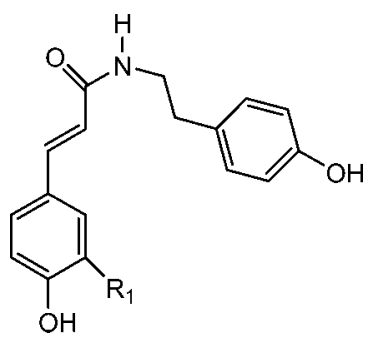

$\mathrm{R}_{1}=\mathrm{H}, p$-Coumaroyltyramine $\mathrm{R}_{1}=\mathrm{OCH}_{3}$, Feruloyltyramine isolation procedure). An important contribution from microcrystalline phases was reported. Heating progressively reduced the birefringence until, at around $50^{\circ} \mathrm{C}$, the field became completely black, confirming the interpretation of the melting behaviour proposed inferred from differential scanning calorimetry (DSC). ${ }^{47}$

A more quantitative study ${ }^{47}$ of the melting of suberin followed the loss of birefringence of a specimen, cooled to $-20^{\circ} \mathrm{C}$, during heating at $5 \mathrm{~K} \mathrm{~min}^{-1}$. After complete melting, the sample was cooled at the same rate. The reversibility of the melting phenomenon observed confirmed the high mobility of the molecules involved in these phase changes. The temperature range of this melting-recrystallisation cycle was $>50 \mathrm{~K}$, corresponding to the wide endothermic peak in the DSC thermograms obtained by Cordeiro and coworkers. ${ }^{46,47}$ These observations strongly suggest that suberin samples consist of a wide distribution of molecular species, as proposed in the literature. ${ }^{47}$

The crystalline character of suberin structures appears not to have been studied; only a mention, ${ }^{39}$ without comment, of the 'melting range' of different suberin fractions has been found in the literature. It was reported that the isolated molecules assemble to give ordered structures, recalling the behaviour of paraffins. However, the presence of $-\mathrm{OH}$ side groups that may favour further intermolecular organisation through hydrogen bonding has also been reported. ${ }^{45}$ The composition of the aromatic fractions of cork suberin also remains to be completely elucidated. The structure of the phenolic component displays features similar to those of lignins. ${ }^{16,17,39,48}$

\section{Lignin}

Although several attempts have been made to extract and characterise cork lignin, its structure has not been fully established. The differentiation between lignin and the aromatic component of suberin had been difficult to establish. A model has been proposed ${ }^{1,34,35}$ in which the lignin/cellulosic matrix bonds to the aromatic domain of suberin, as shown in Fig. 10. The bonding occurs through the dicarboxylic acid and hydroxyl acids and the waxes interact with the aliphatic zone of the suberin polymer. More recent studies of this interaction ${ }^{45,49}$ appear to support this model. These studies, performed using solid ${ }^{13} \mathrm{C}-\mathrm{NMR}$ spectroscopy, showed that the aliphatic portion of suberin is separated from the polysaccharides and lignin, and that the ester bonds of suberin are linked to the lignocellulosic matrix..$^{37,42,45}$
In other studies, ${ }^{50,51}$ hydrolysis of ester bonds between lignin and suberin in reproduction cork samples has been carried out. The samples were treated with sodium methylene in methanol and the residual cork was treated using the Bjorkman procedure to yield a saponified milled cork lignin, which, based on the results of analytical pyrolysis, was claimed to be similar to soft milled lignin from wood. The latter material has been widely studied and serves as a reference for cork. ${ }^{52}$ Wood lignin and cork lignin were studied using ${ }^{13} \mathrm{C}$ NMR spectroscopy and GC-MS. ${ }^{52,53}$ Wood lignin can be severely reticulated and this feature is reflected in the broad resonances of its single NMR pulse spectrum. ${ }^{43}$ Nevertheless, lignins from both cork and wood are of the guaiacyl-type; the spectral differences may be because of differences in the substructures of the guaiacyl units. The MS/NMR spectra are therefore sensitive to the molecular dynamics and chemical structure of ligno-cellulosic materials. Tentative assignments of cork signals based on the chemical shifts observed in solution state NMR spectroscopy of isolated cork components (relative to wood components) have been used to propose a chemical composition for cork lignin. ${ }^{37,45,54}$ For comparison, the model of Gil for the chemical structure of lignin ${ }^{1}$ is presented in Fig. 11.

Oxidation has potential to increase the commercial value of lignin. ${ }^{37,52,53}$ Lignosulfonates have found applications in food products, serving as emulsifiers in animal feed and as raw materials in the production of vanillin; ${ }^{37,55}$ alkaline oxidation of wood or cork lignin

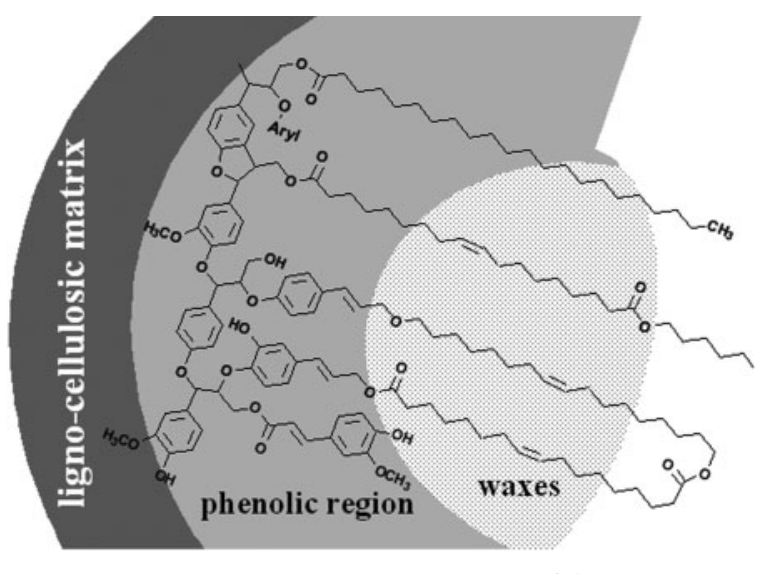

10 Model, proposed by Kolattukudy, ${ }^{179}$ of linkage between lignin/cellulosic matrix and phenolic domain of suberin in cork cell walls 


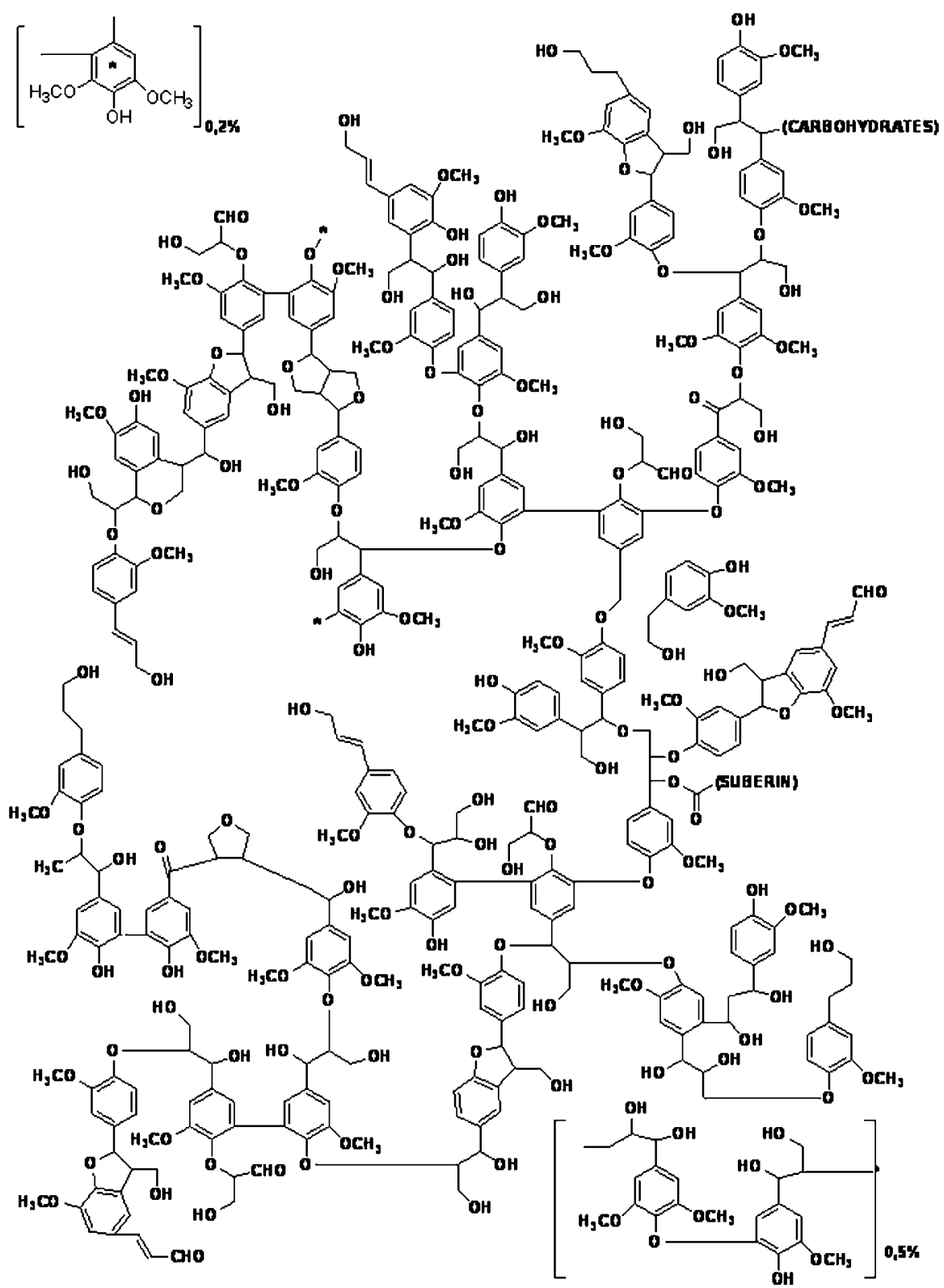

11 Model of chemical structure of lignin in Quercus suber $L$

produces vanillin and vanillic acid. ${ }^{55}$ Vanillin is widely used as an ingredient in food flavours, in pharmaceuticals and as a fragrance in perfumes and odour-masking products. $^{55}$

\section{Polysaccharides}

Besides the principal macromolecular constituents, suberin and lignin, other components present at lower concentrations exert an important influence on the chemical and physical properties of cork. These constituents are compounds with low molecular weight, mainly polysaccharides, waxes and tannins (Table 5).
Cork has a non-negligible yield of polysaccharides but these are one of the less studied components: their percentage may vary from tree to tree and the concentration detected is dependent on the analytical method employed; therefore the results in the literature show considerable variation.

The polysaccharides give structural rigidity to the cork cell, preventing the cells from collapse. ${ }^{20}$ Polysaccharides in cork are cellulose (homopolymer) and hemicellulose (heteropolymer). ${ }^{50,51}$ The degree of polymerisation is also quite different (respectively 1000 and 100-200) and hemicellulose consists of

Table 5 Low molecular weight components of cork

\begin{tabular}{|c|c|c|c|c|}
\hline \multirow[b]{2}{*}{ Component } & \multicolumn{2}{|c|}{ Pereira $^{10}$} & \multirow[b]{2}{*}{ Gil and Moiteiro ${ }^{78}$} & \multirow[b]{2}{*}{ Natividade $^{31}$} \\
\hline & Virgin & Amadia & & \\
\hline Polysaccharides, \% & $11-16$ & $25-30$ & $12-20$ & 22 \\
\hline Waxes, \% & & & $3 \cdot 5-7 \cdot 9$ & 2 \\
\hline Tannins, \% & $17-20$ & 13-14 & $6-7$ & 1 \\
\hline
\end{tabular}




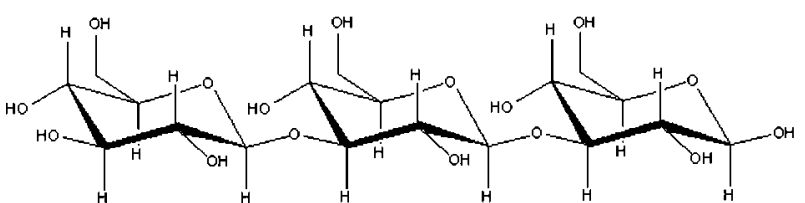

12 Cellulose structure

branched chains. ${ }^{56}$ The polysaccharides consist of a sequence of low molecular weight chains or monomers (Table 6) connected by glycoside linkages.

Generally, hemicellulose and cellulose extraction are performed by hydrolysis methods (alkaline, acid or enzymatic), followed by solvent extraction. ${ }^{57-60}$ Polysaccharides are considered the most heat-sensitive components of cork. ${ }^{61}$ Other important analytical methods for these components are NMR and chromatography. ${ }^{50,51,56,62}$

Several important studies give generic information on cork polysaccharides, ${ }^{50}$ and more specifically on hemicelluloses. ${ }^{63-65}$ Pereira, ${ }^{10}$ after hydrolysis and alditol acetate derivatisation, divided the monosaccharides that compose the carbohydrates of cork into glucose $(50 \cdot 6 \%)$, xylose $(35 \cdot 0 \%)$, arabinose $(7 \cdot 0 \%)$, galactose $(3.6 \%)$ and mannose $(3 \cdot 4 \%)$. A different polysaccharide composition was reported by Asensio ${ }^{50,51}$ using acid hydrolysis: $68 \cdot 8 \%$ of glucose, $20 \cdot 7 \%$ of xylose and small amounts of arabinose, mannose and galactose (respectively $5 \cdot 52 \%, 3 \cdot 52 \%$ and $1 \cdot 83 \%$ ). Cellulose is composed of glucose with $\beta(1 \rightarrow 4)$-D-glucopyranosyl stereochemistry (Fig. 12).

Asensio $^{50,51}$ identified hemicellulose A, B-1 and $\mathrm{B}-2$. Hemicellulose $\mathrm{A}$ is a xylan having $\beta(1 \rightarrow 4)$ glycosidic linkage, 4- $O$-methyl-glucuronoxylan. ${ }^{65} \mathrm{Hemi-}$ cellulose B-1 contains xylose, 4- $O$-methylglucuronic acid, arabinose, galactose, mannose and glucose. ${ }^{63}$ Finally, hemicellulose B-2 is composed of xylose, arabinose, glucose, galactose, 4- $O$-methylglucuronic acid and rhamnose. ${ }^{64}$
It is also possible to evaluate the polysaccharide composition by means of enzymatic hydrolysis, which gives different results: $63 \cdot 9 \%$ of glucose, $7 \cdot 7 \%$ of xylose, $3 \cdot 1 \%$ of arabinose, $8 \cdot 3 \%$ of mannose and $17 \cdot 0 \%$ of galactose. $^{50,51}$

An important conclusion from Pereira's work, ${ }^{20}$ emphasised by Conde et al., ${ }^{66}$ is that in cork, cellulose does not have the same importance as in other wood and barks. In cork, part of its role is played by hemicellulose, particularly xylans.

\section{Extractable components}

Cork stoppers are used for wine bottles because of their impermeability to liquids and air (preventing wine oxidation), compressibility, resilience and chemical inertness. ${ }^{67,68}$ Cork possesses some 'free' components, not chemically linked to the main structure and thus easily extractable with solvents. ${ }^{68}$ Some of these components are responsible for the organoleptic properties of wine. ${ }^{61,69-75}$ This effect has been confirmed by Mazzoleni et al., ${ }^{73}$ who found concentrations of phenolic compounds that exceeded the flavour threshold.

The two most important of these components are waxes and tannins (or more correctly phenolic compounds). ${ }^{34}$ Waxes are extracted by non-polar or low polarity solvents, such as benzene, chloroform, ethyl acetate ${ }^{76}$ hexane ${ }^{77,78}$ and ether. ${ }^{10}$ On the other hand, tannins are extracted by polar solvents such as water ${ }^{79}$ and ethanol. ${ }^{77}$ The yields of these two components also depend strongly on the nature of the cork (virgin or reproduction) and considerable variation is found in the literature. Much work has still to be performed on characterisation of these two families. Supercritical fluid extraction has become an important tool ${ }^{80-84}$ in this respect and presents advantages over conventional extraction processes. ${ }^{85}$ The main advantages claimed ${ }^{80}$ are: the higher purity of extracted compounds and the use of a thermally non-aggressive and non-toxic technology, thereby avoiding degradation of these components. ${ }^{83,86}$ Supercritical fluids may also be used

Table 6 Polysaccharide repetitive monomers

Glucose<smiles>OC[C@H]1O[C@H](O)[C@@H](O)[C@H](O)[C@@H]1O</smiles>

Xylose

Arabinose<smiles>C[C@@H](C=O)[C@@H](O)[C@H](O)CO</smiles>

Methylglucuronic acid<smiles>O[C@@H]1[C@H](O)[C@H](O)OC[C@H]1O</smiles>

Rhamnose<smiles>OC[C@H]1OC(O)[C@H](O)[C@@H](O)[C@@H]1O</smiles><smiles>OC[C@H]1O[C@H](O)[C@@H](O)[C@H](O)[C@@H]1O</smiles><smiles>C[C@@H]1O[C@H](O)[C@H](O)[C@H](O)[C@@H]1O</smiles>

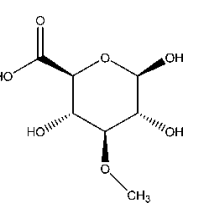

Galactose

Mannose 
Table 7 Some monomeric phenolic structures present in cork

\begin{tabular}{ll}
\hline Epicatechin & Catechin \\
\hline
\end{tabular}<smiles>Oc1cc(O)c2c(c1)O[C@@H](c1ccc(O)c(O)c1)[C@H](O)C2</smiles>

Cyanidin<smiles>Cc1ccc(-c2nc3cc(Br)cc(O)c3cc2Cl)cc1Cl</smiles>

Gallic acid<smiles>C=C(C(=O)O)C1=CC(O)=C(C)C(C)C1</smiles>

Protocatechuic acid

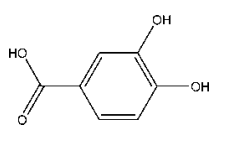

Vanillic acid<smiles>COc1cc(C(=O)O)ccc1O</smiles>

Ferulic acid

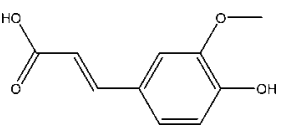

Ellagic acid

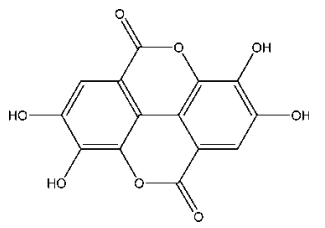

Cinnamic acid<smiles>O=CCCc1ccccc1</smiles>

Syringaldehyde<smiles>C=Cc1cc(OC)c(OC)c(OC)c1</smiles>

p-Coumaric acid<smiles>O=C(O)/C=C/c1ccc(Br)cc1</smiles>

Benzoic acid<smiles>O=Cc1ccccc1</smiles>

Acetovanillone<smiles>COc1cc(C(C)=O)ccc1O</smiles>

to extract lignin, ${ }^{81,87}$ if a correct co-solvent is used, and to transport and introduce desirable components such as preservatives. ${ }^{88,89}$

\section{Phenolic compounds}

Phenolic compounds are solvent extractable components of low molecular weight. Besides phenolic acids or phenolic compounds, this family also includes the chemical families of flavonoids and tannins.

After ether extraction of cork, Conde et $a l^{75}$ found mostly ellagic acid, but also detectable quantities of gallic acid, protocatechuic acid/aldehyde, aesculetin, vanillic acid, caffeic acid, vanillin, scopoletin, ferulic acid, coniferaldehyde and sinapaldehyde (the most representative are listed in Table 7).

Some authors ${ }^{10,31,78}$ have described flavonoids, alkaloids, phenolic and polyphenolic compounds in one main group: tannins. More recently, ${ }^{73,80,90,91}$ these chemical groups have been differentiated, particularly in terms of their potential biological activity.

An ethanolic solution was used by Mazzoleni et al. ${ }^{73}$ to extract the phenolic compounds from powdered cork. Benzoic acid, cinnamic acid derivatives, vanillin, syringaldehyde and acetovanillone were identified, but also caffeic, $p$-coumaric acid, 4-hydroxybenzoic and ferulic acid, depending on the storage and boiling conditions.

Varea et al., ${ }^{61}$ using an ethanolic solution for cork stopper maceration, also showed the important presence of ellagic acid and smaller quantities of gallic acid, protocatechuic acid, caffeic acid, vanillin and ferulic acid.

Tannins may be monomeric or polymeric and can be divided into condensed and hydrolysable tannins (Table 7). After methanolic extraction of cork for $24 \mathrm{~h}$, Conde et $a l^{66}$ observed polymeric structures extracted from cork: roburins A and E, grandini, vescalagin and castalagin (some are shown in Table 8).

\section{Waxes}

Waxes are considered responsible for the impermeability of cork. ${ }^{92,93}$ They are composed of very diverse aliphatic

Table 8 Some polyphenolic structures present in cork

Vescalagin

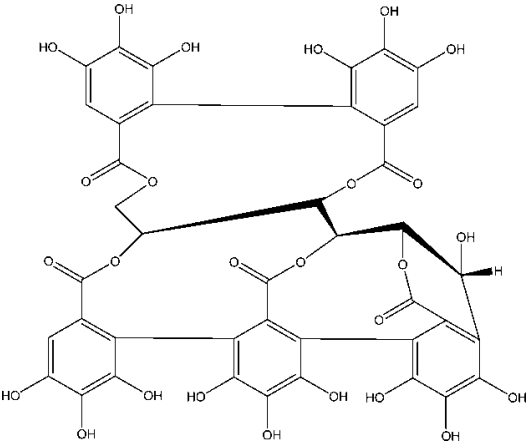

Castalagin

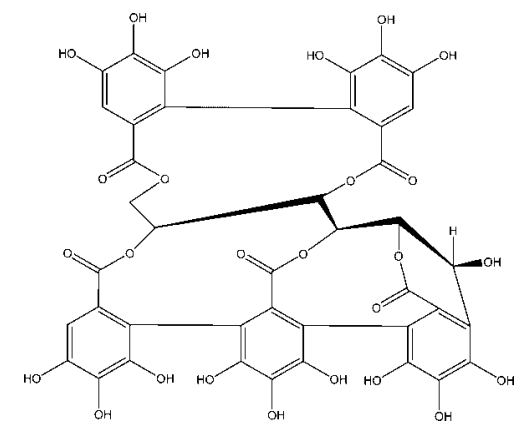


and aromatic compounds. Aliphatics are long chain compounds such as $n$-alkanes, fatty acids, fatty alcohols, glycerol and some triglycerides. About $50 \%$ of the waxes are triterpenes from the friedelin and lupine families. ${ }^{92-94}$

Castola et al., ${ }^{94}$ using dichloromethane, extracted friedelin, 3- $\alpha$-hydroxyfriedelan-2-one, betulin, betulinic acid, $\beta$-sitosterol and sitost-4-en-3-one (Table 9).

Chloroform extraction was used by Conde and colleagues $^{95,96}$ to evaluate the wax composition in different Spanish corks, throughout industrial processing. The waxes extracted were found to consist of two fractions: neutral and acidic. The neutral fraction was mostly composed of fatty alcohols $\left(\mathrm{C}_{18}-\mathrm{C}_{26}\right)$ with a few unsaturated groups and triterpenes. The acid fraction was essentially composed of fatty acids $\left(\mathrm{C}_{14^{-}}\right.$ $\mathrm{C}_{24}$ ) with important unsaturated components, e.g. $\omega$-hydroxyacids, 18-hydroxy-9,12-octadienoic and 18hydroxy-9-octadecenoic acids. The expected compositional variability of waxes from different provenances was clearly shown ${ }^{95}$ but there were also significant changes in wax composition during industrial processing, ${ }^{96}$ particularly in the period after boiling.

\section{Cork properties}

\section{Mechanical properties}

The nomenclature used for directions and sections in cork is that generally used in the description of wood. ${ }^{97}$ Following the nomenclature used in literature and in the section 'Microscopic morphology' above, they will be referred to below as radial (R) or non-radial (NR), the latter corresponding to the tangential or axial direction.

\section{Table 9 Some triterpene structures present in cork}

Friedelin

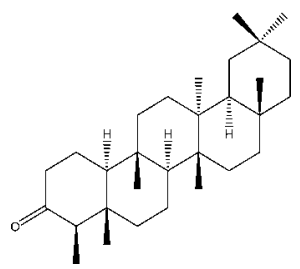

Betulin

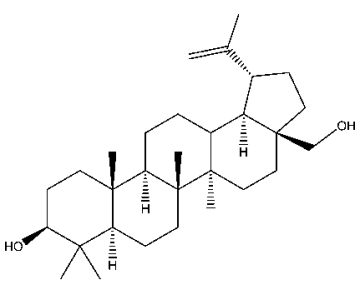

$\beta$-Sitosterol

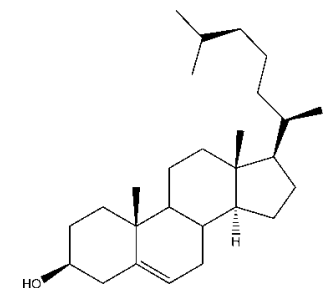

3- $\alpha$-Hydroxyfriedelan-2-one

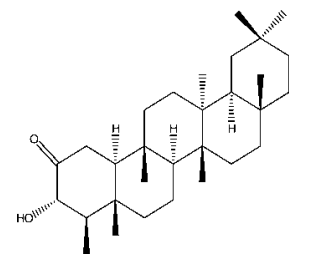

Betulinic acid

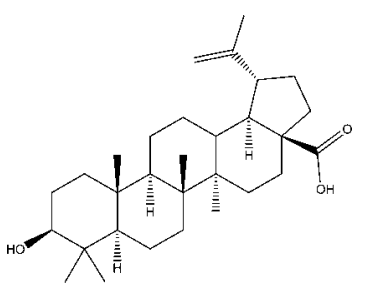

Sitost-4-en-3-one

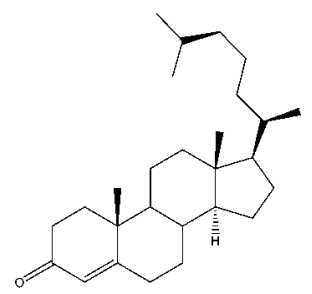

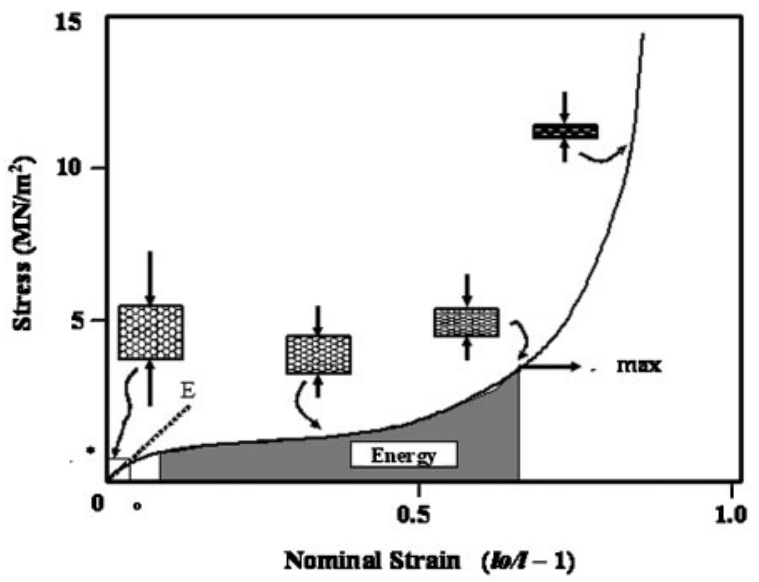

13 Typical compressive stress-strain curve for cork $^{24,28}$ (reprinted from Ref. 28)

Cork presents rather particular mechanical properties. The compression curve (stress-strain) exhibits three regions, related to the three mechanisms responsible

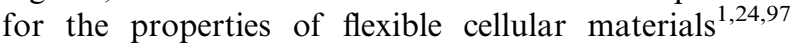
(Fig. 13). The first region, up to about $7 \%$ strain, corresponds to elastic bending of the cell walls; the second is an almost horizontal plateau, which extends to about $70 \%$ strain, caused by progressive buckling of the cell walls; finally, crushing of the cell walls and the complete collapse of the cells cause the curve to rise steeply. ${ }^{24,98,99}$ The collapse stress and strain for cork, corresponding to the end of the plateau regime, are summarised in Table 10.

The staggered and random arrangement of cell bases $^{6,24}$ and the corrugation of lateral cell walls influence the Poisson coefficient $(v)$, which provides some of cork's most interesting properties that lead to its diverse applications. ${ }^{100,101}$ When cork is compressed in the radial direction, the cell walls fold and pack due to the corrugations, the amplitude of corrugations increases and the cell bases perpendicular to the $\mathrm{R}$ direction align. Both these effects cause a small expansion in the NR direction, which results in a small positive value for $v$. When the compression is in the NR direction, the lateral cell walls bend, straighten and, at high strains, invert the undulation pattern, which leads to shrinkage in the $\mathrm{R}$ direction and hence to a negative Poisson ratio at high strains. ${ }^{100}$

Cork planks have different thicknesses (as a result of differences in cork growth rate). Calibre, i.e. thickness of the planks, has an important effect on mechanical properties. ${ }^{102,103}$ In compression, higher calibres have lower compression strength and modulus. ${ }^{102}$ Young's modulus values obtained for cork of different calibre in compression parallel to each of the three principal directions are reported in Table $11 .^{102}$ The higher strength and modulus could be because of the larger proportion of late cork cells in thin planks, since these cells have higher mechanical strength (due to their higher thickness and reduced degree of corrugation).

The lower strength in compression in all three principal directions and lower Young's modulus of cork with higher calibre can largely be accounted for by differences in cell dimensions and in the corrugation pattern; in the tangential and axial directions, the effect 
Table 10 General mechanical properties of cork

\begin{tabular}{lll}
\hline Property & Value & Ref. \\
\hline Compressive modulus, natural cork, unboiled, MPa & $8-20(\mathrm{R})$ & $105,107,111$ \\
Compressive modulus, boiled, $\mathrm{MPa}$ & $13-15(\mathrm{NR})$ & 107 \\
& $6(\mathrm{R})$ & 107 \\
Compressive modulus, heat treated at $100^{\circ} \mathrm{C}, 28$ days, $\mathrm{MPa}$ & $8-9(\mathrm{NR})$ & 107 \\
& $11(\mathrm{R})$ & 105 \\
Compressive modulus, heat treated at $150^{\circ} \mathrm{C}, 28$ days, $\mathrm{MPa}$ & $11(\mathrm{NR})$ & 105 \\
& $15(\mathrm{R})$ & 105 \\
Tensile modulus, boiled, MPa & $14(\mathrm{NR})$ & 105 \\
Collapse (buckling) stress, boiled, MPa & $38(\mathrm{R})$ & 97 \\
& $24-26(\mathrm{NR})$ & 97 \\
Collapse (buckling) strain, \% & $0 \cdot 75-0 \cdot 8(\mathrm{R})$ & 24,111 \\
& $0 \cdot 6-0 \cdot 7(\mathrm{NR})$ & 24,111 \\
Fracture stress under tension, MPa & $4(\mathrm{R})$ & 24 \\
Fracture strain under tension, \% & $6(\mathrm{NR})$ & 24 \\
Fracture toughness, boiled, MPa m ${ }^{1 / 2}$ & $1 \cdot 0(\mathrm{R})$ & 24 \\
Poisson's ratio, boiled & $1 \cdot 1(\mathrm{NR})$ & 24 \\
& $5(\mathrm{R})$ & 24 \\
Loss coefficient at 0.01 Hz & $9(\mathrm{NR})$ & 24 \\
\hline
\end{tabular}

$\mathrm{R}$, measured in radial direction; NR, measured in non-radial directions.

of pores should also be included in compression models. ${ }^{27}$

Heat treatment in air affects the compression properties of reproduction cork. Rosa and Fortes ${ }^{104}$ reported that treatment at $100-300^{\circ} \mathrm{C}$ considerably reduced the strength of cork. After heating at $200^{\circ} \mathrm{C}$, the Young's modulus decreased by a factor of about 3, and after heating at $300^{\circ} \mathrm{C}$, by a factor of 15 . The specific Young's modulus (modulus/density) also decreased, by a factor of $5-10$ at $300^{\circ} \mathrm{C}$.

Heated to $100-150^{\circ} \mathrm{C}$ for 1 day, is reported to increase compression strength as a result of water loss. Longer treatments (1-14 days) at the same temperature produce a decrease in the compression strength, presumably related to thermomechanical degradation. ${ }^{105}$

Heat treatment with water (the industrial process of 'boiling' ${ }^{106}$ ) also affects the mechanical properties of cork. Water absorption during boiling softens the cell walls, while pressure differences between adjacent cells induce tensile stresses sufficient to straighten the walls. ${ }^{107}$ This causes three main changes in mechanical properties: reduction in strength and in anisotropy (particularly in the elastic region) and the appearance of a sharper yield point during compression in the $\mathrm{R}$ direction. The last effect is strongly related to the reduction in the amplitude of corrugations, since with higher amplitudes, the yield transition becomes less sharp and the plateau region less well defined.

Table 11 Young's modulus values obtained in compression moulding parallel to each of three principal directions for cork of different calibre (after boiling) ${ }^{102}$

\begin{tabular}{|c|c|c|c|}
\hline \multirow[b]{2}{*}{ Cork calibre } & \multicolumn{3}{|l|}{$E, \mathrm{MPa}$} \\
\hline & Radial & Axial & Tangential \\
\hline Small & $11 \cdot 5 \pm 1 \cdot 0$ & $10 \cdot 9 \pm 0 \cdot 6$ & $8 \cdot 6 \pm 0 \cdot 7$ \\
\hline Medium & $13 \cdot 2 \pm 0 \cdot 7$ & $12 \cdot 0 \pm 1 \cdot 5$ & $9 \cdot 6 \pm 1 \cdot 4$ \\
\hline Large & $9 \cdot 9 \pm 0.4$ & $9 \cdot 2 \pm 0.5$ & $7 \cdot 9 \pm 1 \cdot 3$ \\
\hline
\end{tabular}

Average tensile stress-strain curves are shown in Fig. $14,9^{97}$ the properties obtained are summarised in Table 10. The curves for the two NR directions (A and $\mathrm{T})$ are quite different from that for the $\mathrm{R}$ direction, which shows an intermediate region with serrations. This intermediate region has been explained in terms of the appearance of successive microcracks that propagate across only a few surrounding cells before growth is arrested. ${ }^{97}$

In general, cork exhibits different behaviour in tension and in compression. Rosa and Fortes ${ }^{97}$ reported that the Young's modulus in compression is appreciably smaller than that in tension. The larger modulus in tension can be explained in terms of the stiffness of undulated plates (cell walls), which increases as the amplitude of the undulations decreases: compression increases the amplitude, whereas tension decreases it. ${ }^{1,97}$

\section{Physical properties}

The study of properties other than mechanical has not been extensive, although they are clearly important for many current applications of cork. Most published work

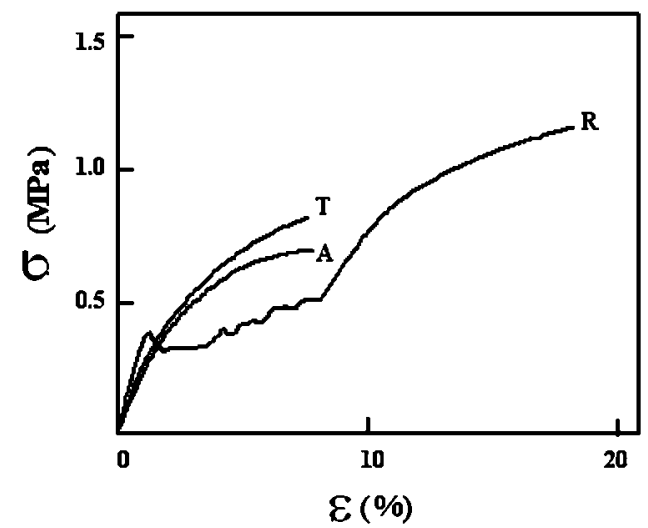

14 Stress-strain curves in tensile tests for cork, in all directions: $T$, tangential; $A$, axial; $R$, radial ${ }^{97}$ 


\begin{tabular}{|c|c|c|}
\hline Property & Value & Ref. \\
\hline \multirow[t]{5}{*}{ Friction coefficient, boiled } & $0 \cdot 2-1 \cdot 2$ (cork/glass and cork/steel) & 111 \\
\hline & 0.97 (cork/cork, R) & 111 \\
\hline & 0.77 (cork/cork, NR) & 111 \\
\hline & $0 \cdot 76$ (cork/glass, R) & 111 \\
\hline & 0.35 (cork/glass, NR) & 111 \\
\hline \multirow[t]{2}{*}{ Density, $\mathrm{kg} \mathrm{m}^{-3}$} & 120-180 (amadia) & 29 \\
\hline & $160-240$ (virgin) & 29 \\
\hline \multirow[t]{2}{*}{ Surface energy, dispersive component, $\mathrm{mJ} \mathrm{m}^{-2}$} & $24-38\left(40^{\circ} \mathrm{C}\right)$ & 32,108 \\
\hline & $41\left(25^{\circ} \mathrm{C}\right)$ & 171 \\
\hline \multirow[t]{3}{*}{ 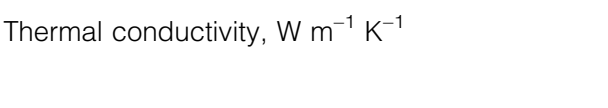 } & 0.045 (cork) & 1 \\
\hline & 0.025 (air) & 1 \\
\hline & 0.2 (cork cell walls) & 1 \\
\hline \multirow[t]{2}{*}{ Electrical conductivity, $\mathrm{S} \mathrm{m}^{-1}$} & $1.2 \times 10^{-10}\left(25^{\circ} \mathrm{C}\right)$ & 100 \\
\hline & $1.67 \times 10^{-13}\left(50^{\circ} \mathrm{C}\right)$ & 100 \\
\hline Acoustic resistivity, $\mathrm{kg} \mathrm{m}^{-2} \mathrm{~s}^{-1}$ & $1.2 \times 10^{5}$ & 177 \\
\hline Specific heat, $\mathrm{J} \mathrm{kg}^{-1} \mathrm{~K}^{-1}$ & 350 & 1 \\
\hline Thermal diffusivity, $\mathrm{m}^{2} \mathrm{~s}^{-1}$ & $1 \times 10^{-6}$ & 1 \\
\hline \multirow[t]{2}{*}{ Water diffusion coefficient, $\mathrm{m}^{2} \mathrm{~s}^{-1}$} & $4 \times 10^{-10}(\mathrm{NR})$ & 1 \\
\hline & $1 \times 10^{-11}(\mathrm{R})$ & 1 \\
\hline
\end{tabular}

$\mathrm{R}$, measured in radial direction; NR, measured in non-radial directions.

refers to the insulation properties, water impermeability and, more recently, surface and dielectric properties. Physical properties reported in the literature are compiled in Table 12.

Gomes et al. ${ }^{108}$ were the first to measure contact angles and surface properties of cork. They found that $n$ alkanes spread spontaneously on the surface with zero contact angle. Owing to the anisotropy of cork surfaces, the drops were slightly elongated in the $\mathrm{R}$ direction. Cork showed a high affinity for non-polar liquids and a very low polarity, comparable with those of fluorinated polymers (around $75 \%$ of intermolecular interactions arise from dispersion forces). Inverse gas chromatography has also been applied to study the surface properties of cork. ${ }^{32}$ The surface energy measured by this method (Table 12) is much higher than that obtained by contact angle measurements, due probably to the influence of surface heterogeneity. Evaluation with polar probes showed that the surface of cork is amphoteric, making it compatible with both acidic and basic polymeric functional groups.

The low density of cork is due mainly to the high gas content of the small cells (typically $40 \mu \mathrm{m}$ long, as discussed above). Both gas content and cell size account for the very poor heat transfer properties of cork. Heat can be transmitted by conduction (which depends on the amount of solid in the structure), convection (which is significant only for high volumes of gas) and radiation (which becomes less efficient with decrease in cell size). ${ }^{28}$ In cork, only conduction has importance for heat transfer; even so, the thermal conductivity of the walls will be only slightly higher than that of the gas in the cells (Table 12). ${ }^{1}$

Similarly, sound transmission is very poor, owing to the low density and high porosity of cork; most of the incident sound waves are absorbed and transformed into heat energy, which reduces reverberation. ${ }^{1}$ This is especially significant for expanded corkboard (or black agglomerate $^{109}$ ), which will be discussed below.

The friction properties of cork and its high damping capacity are important in many applications, including shoe soles, stoppers and handles of tools. ${ }^{110}$ The friction coefficient of a cork stopper (based on the force required to extract it from the bottle) is around 0.5. ${ }^{105}$ As with many other properties, the friction coefficient is anisotropic, being higher for sliding in the tangential plane than in those planes perpendicular to it; this anisotropy becomes less pronounced for humid cork. ${ }^{111}$ The friction behaviour of cork on other surfaces depends on the adhesion (related to the contact area and friction coefficient of the broken cell walls) and on the deformation by bending of the cell walls (related to the roughness of the counter-surface and to the bending stiffness of the walls). ${ }^{111}$

The thermal transitions of cork have been studied by a range of techniques, including dielectric, thermomechanical and calorimetric analysis. ${ }^{110,112-114}$ When submitted to static electrical fields, cork exhibits a complex pattern of relaxation mechanisms. ${ }^{113}$ Cork contains more than $3.5 \%$ absorbed and adsorbed water at ambient relative humidity, which is likely to produce important modifications in its physical properties. ${ }^{114-116}$

Thermally simulated discharging current (TSDC) analysis has shown that at least three different mechanisms can be distinguished: ${ }^{112,113}$ (i) a low temperature relaxation observed between -100 and $-50^{\circ} \mathrm{C}$, which was attributed to local motion arising from slightly hindered internal rotation of polar groups in the polymeric chains constituting the walls of the cork cells; (ii) a relaxation mechanism which was attributed to a glass transition like relaxation process; (iii) a higher temperature mechanism observed at $30-80^{\circ} \mathrm{C}$ which is probably because of the melting of waxes present in cork. ${ }^{112,113}$ For all these reasons, and since it is a dielectric material, cork is used as an electric insulator.

Dynamic mechanical analysis has been applied to cork, with results similar to those reported above. ${ }^{110} \mathrm{~A}$ complex relaxation was found, with maximum intensity $\tan \delta$ at $\sim 20^{\circ} \mathrm{C}$. This process has an activation energy of approximately $140 \mathrm{~kJ} \mathrm{~mol}^{-1}$ and was attributed to a glass-transition like process within a component of cork, probably suberin. Annealing of cork specimens gave higher stiffness and lower damping, thought to be related to desorption of water molecules from the cork structure. The dielectric properties of cork were influenced to a greater extent by desorption of 


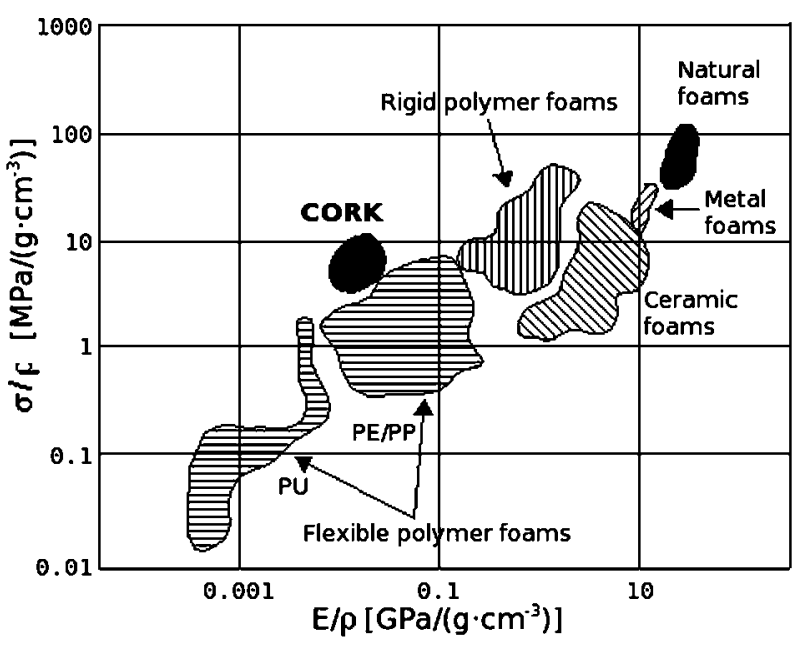

15 Materials selection chart comparing specific compressive strength $(\sigma / \rho)$ with specific modulus $(E / \rho)$ (adapted from Ref. 28)

water, owing to the strong polar character of the water molecules. ${ }^{110,113}$

Differential scanning calorimetric results (up to $100^{\circ} \mathrm{C}$ ) only showed the presence of an endothermic peak at $75-80^{\circ} \mathrm{C}$, with an enthalpy of $5 \cdot 5 \mathrm{~J} \mathrm{~g}^{-1}$. ${ }^{110}$ This phase transition was assigned to the melting of waxes present in cork, and seems to corroborate results found using TSDC. ${ }^{110,113}$

\section{Comparison with other foamed materials}

It is of interest to compare the properties of cork with those of other natural and synthetic foams. Cork has a limited range of variation in properties, owing to its defined morphology and structure (with only minor variations, as described above). Therefore, it is not possible to obtain the vast range of properties possible with, for example, polyurethane (PU) or polyethylene (PE) foams. Nonetheless, cork can compete with the best synthetic materials in specific applications.

The relatively poor mechanical properties limit the engineering applications of cork. The materials selection map in Fig. 15 plots specific modulus and specific compressive strength (the best materials are those located at the top right corner). Foams with rigid cell walls (metals, ceramics) will obviously offer much more resistance to mechanical loads than the undulated walls of cork, presenting higher specific stiffness. However, although lacking stiffness, cork cells are strong and the specific strength of cork is as good as any rigid synthetic foam. Globally, it presents mechanical properties equivalent to those of flexible polymer foams. For this reason, cork is useful in load bearing applications only as a filler in other plastics/elastomers, usually for providing good damping properties (see below).

Cork appears to have more advantages when comparing thermal conductivity and compressive strength (Fig. 16). Its low thermal conductivity plus reasonable compressive strength make it an excellent material for thermal insulation where compressive loads are present. The best materials on this map fall in the bottom right corner, and cork performs similarly to synthetic rigid polymer foams.

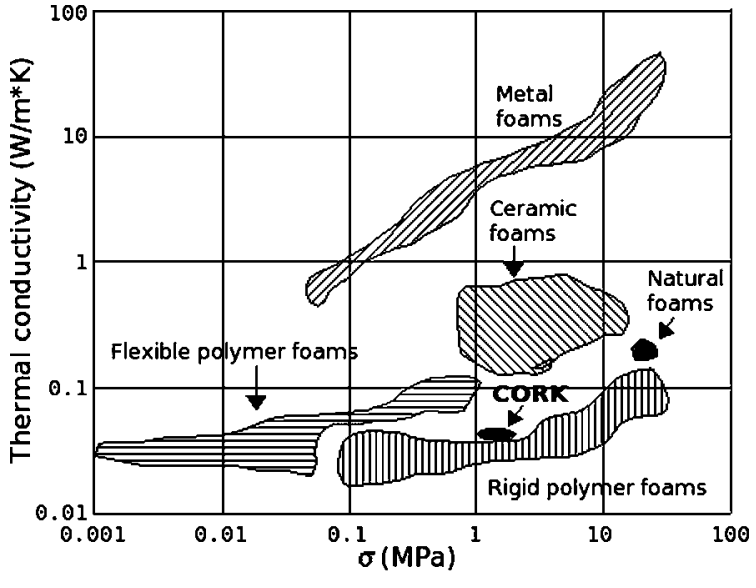

16 Materials selection chart comparing thermal conductivity with compressive strength $(\sigma)$ (adapted from Ref. 28)

\section{Natural cork applications}

Cork's unique combination of a high coefficient of friction, resilience, high energy absorption, excellent insulation properties and near-zero Poisson coefficient makes it the optimum (or only) material for a variety of applications. In addition, it is a natural and renewable product.

Cork has a wide range of traditional applications. Natural cork stoppers remain the gold standard of cork applications, having the highest added-value and largest market. However, the fact that the byproducts of stopper production are used in other applications should not be overlooked. The main industrial applications of cork are reviewed below. Many of the processes described are generally known and used but appear not to have been described in the scientific literature or in patents.

\section{Natural cork stoppers}

For several centuries, cork has proved to be the most effective closure for wine, protecting its qualities and allowing it to develop and improve over time. The technology of stopping wine bottles with clean, unsealed cork was perfected by Benedictine monks in the seventh century. ${ }^{1,24}$ Then, in 1680 , the first use of cork to seal champagne by Don Pierre Pérignon started a revolution in wine bottling. ${ }^{1,19,117}$ The impermeability of cork to liquids and gases, derived from the fact that its closed cell walls are made up mainly of suberin, and its high compressibility and flexibility, make it ideal for sealing bottles. $1,19,117$ Cork is recommended for bottles of reserve wines and wines that need to age in the bottle. Natural cork stoppers are punched direct from the best quality cork bark.

After harvesting, the cork planks are stabilised by storing for at least 6 months to oxidise the polyphenols and stabilise the cork texture. The stabilised planks are boiled in clean water for at least an hour to make them more pliable and to fully expand the lenticels. The gas in the cells expands to create a very tight, uniform cell structure. Boiling causes the cork to increase in volume and become flatter and smoother; at the same time, the microflora population is significantly reduced. Many manufacturers use complementary procedures to improve cleanliness, ${ }^{118}$ e.g. an autoclave process with water to wash planks for champagne stoppers. ${ }^{119}$ 


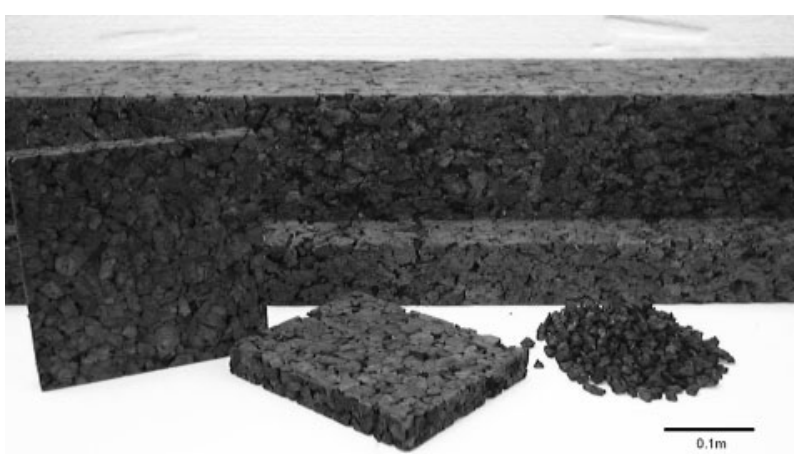

17 Some of different shapes of insulation corkboard and regranulated ICB

After boiling, the planks are dried and stored at controlled humidity and temperature for some weeks then sorted by thickness and quality (dependent on porosity and level of structural defects). After this 'resting' period, the stoppers are punched (manually or automatically) and the remaining material sorted and classified for use as agglomerate stoppers, discs or agglomerated products. ${ }^{1,19}$ The best seal is obtained when the axis of the stopper is parallel to the prism axis of the cork cells, so that the circular symmetry of the cork and its properties are used to best advantage. ${ }^{28}$ Each raw cork stopper is cut to size, polished and graded. ${ }^{120}$ Wine corks are graded in up to seven categories. ${ }^{19,121}$ The final quality depends on the raw material and the processes adopted by the manufacturer. All natural cork stoppers are cylindrical in shape.

The selected stoppers undergo washing and disinfection, ${ }^{122}$ most commonly by washing in an aqueous solution of hydrogen peroxide. More recently, microwave $^{123,124}$ or ozone disinfection techniques have been applied to avoid contamination arising from the presence of primers. ${ }^{125}$

Various approaches have been adopted to avoid unpleasant aromas that could change the sensory characteristics of the wine. For example, new sterilisation processes have been developed that extract volatile substances. ${ }^{126}$ Other systems applied in the industry, such as the ROSA system, ${ }^{125}$ diminish significantly the microbial load in natural or technical cork stoppers. Supercritical fluid extraction is also employed. ${ }^{82}$ There is no wholly efficient method, but these preventive measures greatly reduce the occurrence of contaminated batches of cork.

Next, the stoppers are dried in special stoves. When the moisture level has been lowered and stabilised, stopper performance is maximised and microbial contamination minimised. Drying eliminates internal moisture from the cork without changing or damaging the cell structure, providing a further barrier to microbial contamination. After a final selection, the cork stoppers may be printed.

Before sale, quality control is typically performed for size/density, humidity, tightness for gases and liquids and microbiological tests. ${ }^{72}$ Finally, the stoppers are automatically counted, sterilised with sulphur dioxide gas and sealed in gas-barrier bags.

No other stopper combines cork's inert nature, impermeability, flexibility, sealing ability and resilience. Being a natural product, cork is also environmentally friendly, renewable and recyclable. The 'breathability' promoted by cork will also have a positive influence on wine, similar to that achieved by oak wood aging. ${ }^{127,128}$

The alternatives to cork stoppers are synthetic materials, synthetic stoppers and screw caps, but very few studies have been carried out to assess the long term non-toxic effects and other characteristics of these materials. ${ }^{117,129,130}$ Synthetic stoppers are easier to manufacture, cheaper and avoid contamination of wines by cork components. On the other hand, toxic compounds arising from the synthesis and processing of the polymer may be released during storage. Screw caps are easier to remove and the best choice for situations where a corkscrew is inconvenient (airplanes, small bottles, 'take-away', etc.); however aluminium is not an inert material and may be attacked by the wine, releasing metal ions.

\section{Insulation corkboard}

For insulation applications, agglomerates of granules of cork, known as black agglomerates, are employed. They are manufactured in a closed autoclave at high temperature (approximately $300^{\circ} \mathrm{C}$ ) and pressure (around $40 \mathrm{kPa}$ ) without the use of adhesive. ${ }^{25,30}$ This industrial process induces thermochemical degradation of the cork cell wall, ${ }^{27}$ with prior expansion of these granules, as discussed elsewhere. ${ }^{107}$ The degradation byproducts act as natural adhesives between granules to form the corkboard. ${ }^{27,53,104}$

It has been reported that suberin acts as the main binding agent in insulation corkboard. ${ }^{53}$ The agglomeration of natural cork (Fig. 17) was discovered accidentally in 1891 by an American life-guard and manufacturer of lifejackets called John Smith.

Such expanded black agglomerates are produced from the lowest quality and residual corks, mainly from winter virgin cork (from pruning and dead trees) unsuitable for other applications or from cork wastes and residues from other industrial processes. ${ }^{78,131,132} \mathrm{~A}$ high impurity content impedes adhesion between the cork particles by affecting the efficacy of the binding agent in the agglomeration process. ${ }^{131}$

After forming, the blocks are transferred to a cooling machine that injects recycled water (at close to $100^{\circ} \mathrm{C}$ ) for drying and stabilisation. Finally, they are cut to the size and thickness desired. The off-cuts are re-granulated and recycled.

In agglomeration, the cork cells expand by unfolding the cell wall corrugations and by wall stretching, therefore cell wall thickness decreases. At the junctions between granules, cells are compressed and collapse. The expansion results in an increase in cell volume of about $100 \%$, and the thermochemically degraded cell wall material is responsible for the final dark appearance and the weight loss (approximately $30 \%$ of the initial weight). ${ }^{25,78}$ This weight loss can be explained on the basis that the amount of extractable compounds decreases rapidly, together with the rapid loss of polysaccharides that always occurs at temperatures above $200^{\circ} \mathrm{C}$. It is also known that hemicelluloses have lower thermal stability than cellulose and lignin, as confirmed by their degradation over the range $180-360^{\circ} \mathrm{C}^{27}$

The temperature and pressure applied lead to all granules becoming covered by suberin and waxes that can diffuse and deposit on the cork granule surfaces. The hydrophobic character of these components 
Table 13 Properties of insulation cork agglomerate ${ }^{25,133}$

\begin{tabular}{ll}
\hline Property & Range of values \\
\hline Density, $\mathrm{kg} \mathrm{m}^{-3}$ & $100-130$ \\
Working temperature, $\mathrm{K}$ & $97-383$ \\
Thermal conductivity $\left(20^{\circ} \mathrm{C}\right), \mathrm{KJ} \mathrm{m}^{-1} \mathrm{~s}^{-1} \mathrm{~K}^{-1}$ & $4 \cdot 1 \times 10^{-5}$ \\
Specific heat $\left(20^{\circ} \mathrm{C}\right), \mathrm{kJ} \mathrm{kg}^{-1} \mathrm{~K}^{-1}$ & $1 \cdot 7-2 \cdot 1$ \\
Thermal expansion coefficient & $40 \times 10^{-6}$ \\
Permeability to steam, $\mathrm{kg} \mathrm{Pa}^{-1} \mathrm{~s}^{-1} \mathrm{~m}^{-1}$ & $4 \cdot 2 \times 10^{-12}$ to $12 \times 10^{-12}$ \\
Tensile strength, $\mathrm{MPa}$ & $0 \cdot 05$ \\
Compressive strength at $10 \%, \mathrm{MPa}$ & $0 \cdot 25$ \\
Bending tension*, $\mathrm{KN} \mathrm{m}^{-2}$ & $1 \cdot 6 \times 10^{-4}$ \\
\hline
\end{tabular}

*Force for bending material with cross surface.

contributes to the black agglomerate's low humidity absorption and low diffusivity of water vapour. ${ }^{25,133}$ The properties of insulation corkboard are summarised in Table 13.

An important advantage of insulation corkboard is its resistance to chemical and biological agents. ${ }^{1}$ The agglomerate reacts only in the presence of strong acid solutions that disaggregate it; it also reacts weakly with ethyl acetate, trichloroethylene and solutions of acetic acid or ammonia at $10 \%{ }^{133}$

Insulation corkboard agglomerates have three principal applications: ${ }^{25}$ thermal insulation, acoustical absorption and vibration damping (Table 14). Corkboard maintains its physical properties to lower temperatures than other insulator materials (working temperature range -180 to $\left.110^{\circ} \mathrm{C}\right)^{25}$ and under fire conditions does not release toxic substances as may occur with alternative materials such as polyurethane foams, or extruded and expanded polystyrene. ${ }^{133}$

Thus cork agglomerates are suitable for diverse construction applications, interior or exterior walls, buildings and ceilings, to provide thermal and acoustic insulation and sub-paving insulation to minimise transmission of repercussion noises. ${ }^{133-135}$ Another advantage of this agglomerate is the fact that it is a wholly natural material (without chemical additives) and reusable.

\section{Other applications}

During stopper production, a large amount of cork is not used because it is unsuitable or is discarded during production. This material is granulated and used in a variety of applications, mainly for production of cork/ rubber composites, general purpose agglomerates ${ }^{136}$ and agglomerates for wall ${ }^{137}$ and floor coverings.

For the production of agglomerates, cork granules are mixed with a polymeric binder and compressed under heat and pressure. The most important variables in this processes are size and fraction of cork granules in the mixture (as high as $90 \mathrm{wt}-\%$ ), type of polymeric binder (polyurethanes, phenol-formaldehyde resins, etc.) and packing density. The resultant blocks are laminated, shaped to final dimensions and finished. Articles such as shoe soles, ${ }^{138}$ memoboards, gifts and panels are produced in this way. The high coefficient of friction and damping capacity of cork are important for applications as shoe soles, while its ability to absorb energy during impact makes the agglomerates suitable for mechanical insulation of goods. Bulletin boards profit from the collapse of cell walls during compression (therefore only a small force is needed for indentation) and almost complete recovery after pin removal. ${ }^{28}$

Agglomerates for decorative floor panels are made in a similar way, but stiffer and stronger. This is usually accomplished by changing the packing pressure or using a different binder. In some cases, a protective polymeric layer is employed to increase wear resistance. These agglomerates can be employed alone or in multilayer products $^{139}$ (together with wooden high density fibreboard, polymeric and adhesive layers). The most important properties of cork for this application are its high resilience and energy absorption, near zero Poisson's coefficient (for higher comfort during walking) and high coefficient of friction.

Cork/rubber composites are produced by adding cork granules to a rubber formulation; the mixture is then compounded, vulcanised, shaped and finished. Almost all types of rubber can be compounded with cork. ${ }^{140}$ The main application for these composites is as gaskets ${ }^{141}$ for automobiles and oil containers: besides being impervious to liquids, the low Poisson ratio of cork means that these gaskets do not suffer from excessive lateral expansion. ${ }^{100}$

\section{Future trends}

To date, the cork industry and general public have viewed cork mainly in terms of stoppers. However, innovation is increasingly occurring in this traditional industry.

Cork has specific properties (physical, chemical and mechanical) that confer great potential for new applications. The increased interest in natural products has also been an important factor in this change of attitude. For example, cork has been chosen for some aerospace application because of its thermal properties, slow burn rate and shock absorption capacity. ${ }^{142}$

Table 14 Some properties of different types of corkboard agglomerate ${ }^{133}$

\begin{tabular}{|c|c|c|c|}
\hline Type of insulation & Density, $\mathrm{kg} \mathrm{m}^{-3}$ & $\begin{array}{l}\text { Thermal conductivity at } \\
20^{\circ} \mathrm{C}\left(\times 10^{-5} \mathrm{~kJ} \mathrm{~m}^{-1} \mathrm{~s}^{-1} \mathrm{~K}^{-1}\right)\end{array}$ & $\begin{array}{l}\text { Permeability to water vapour } \\
\left(\times 10^{-12} \mathrm{~kg} \mathrm{~Pa}^{-1} \mathrm{~s}^{-1} \mathrm{~m}^{-1}\right)\end{array}$ \\
\hline Acoustical & $80-100$ & $3 \cdot 7$ & $8 \cdot 3-21$ \\
\hline Thermal & $100-150$ & $4 \cdot 0-4 \cdot 2$ & $4 \cdot 2-12$ \\
\hline Anti-vibration & $175-320$ & $4 \cdot 8-5 \cdot 7$ & $2 \cdot 1-8 \cdot 3$ \\
\hline
\end{tabular}




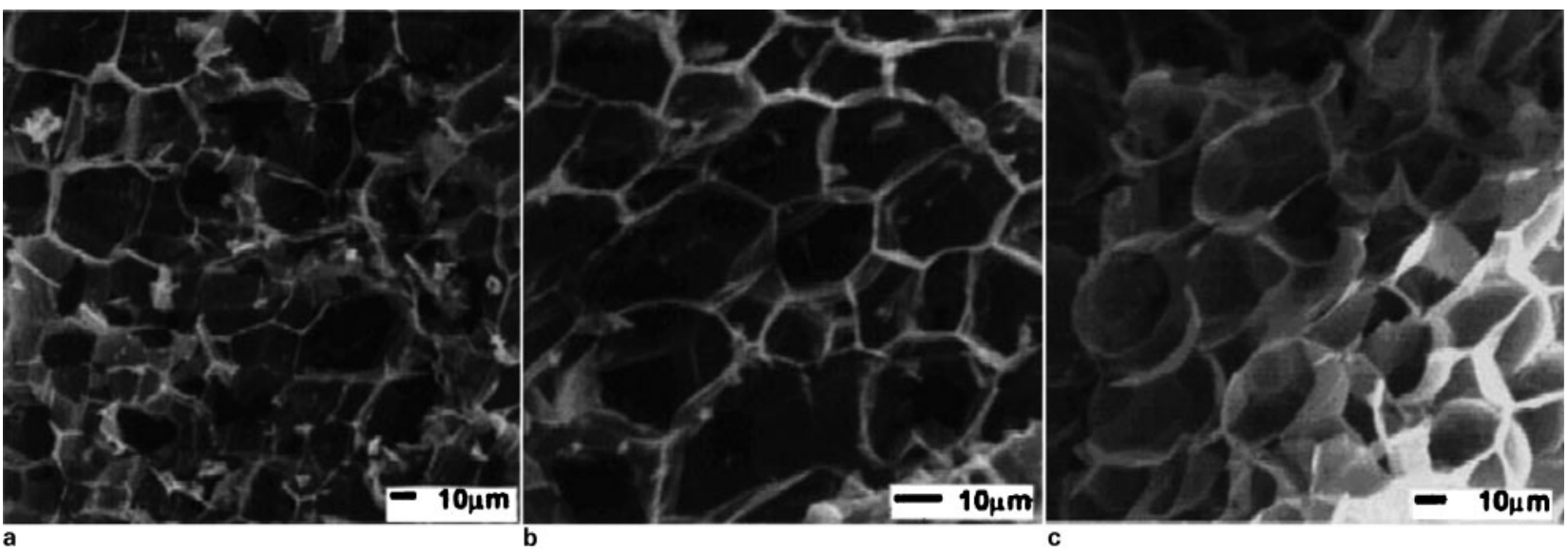

a cork carbonised at $800^{\circ} \mathrm{C}$ under nitrogen; $b$ cork carbonised and physically activated to $64.5 \%$ burn-off; $c$ chemical activated cork

18 SEM micrographs of cork (reprinted from Ref. 152, ๑1999, with permission from Elsevier)

\section{Sorption capacity}

Most cork companies consider cork powder as a waste product and use it only as an energy source as a result of its low economic value and high burning capacity. ${ }^{143}$ However, as biosorption (sorption of contaminants by sorbents of natural origin) has gained in importance, the good performance and low cost of cork as a complexing material have become attractive. ${ }^{144,145}$

For instance, adsorptive removal of heavy metals in waste water is usually achieved using activated carbon, activated alumina or polymer resins, which are nonregenerable and expensive materials. ${ }^{146}$ Thus, a need does exist for low cost, effective, regenerable adsorbent materials in this application. The fatty acid content of cork makes it a promising biosorbent for heavy metal, oils, etc. Such biosorbents must in general be selective for specific contaminants and easily disposed of by incineration. ${ }^{147}$ Biosorbants for wastewater treatment must also be cheap, given the large volumes of effluent involved. ${ }^{148}$ Studies have reported the advantages of cork for the biosorption of heavy metals such as $\mathrm{Cu}$ (II), $\mathrm{Zn}(\mathrm{II}), \mathrm{Cr}(\mathrm{VI})$ and $\mathrm{Ni}(\mathrm{II}) .{ }^{145,146,149,150}$

At low concentrations, these chemical contaminants are difficult to remove from aqueous solutions. The more common removal techniques used, ${ }^{151}$ e.g. chemical precipitation and reverse osmosis, become inefficient when contaminants are present at trace concentrations. The adsorption processes are one of the few alternatives available and again cork presents good properties for those applications.

Biosorption is expected to show strong future growth because it offers high cost effectiveness; it is an emergent technology and further improvements in both performance and costs can be expected. Environmental protection legislation is becoming increasingly important and effective solutions will be at a premium. ${ }^{148}$

\section{Activated carbon}

Another new application is the transformation of cork to activated carbon by physical and chemical activation. ${ }^{152-154}$ Activated carbons can be prepared from a wide variety of natural and synthetic polymeric ${ }^{152}$ or mineral ${ }^{155}$ materials (e.g. bentonites, diatomites or zeolites).

The production of activated carbon from cork has been the subject of only limited research. ${ }^{153,154}$ The micropore volume, an important characteristic, was found to be similar to that of current commercial activated carbons (e.g. Takeda products ${ }^{156}$ ). These preliminary studies revealed adsorption properties different from other activated carbons, which may be of interest for novel filter applications. One such application is for separation of natural gas components where the high selectivity between small gas molecules of this activated carbon would be advantageous. ${ }^{154}$

Figure $18 a$ shows the structure of cork after carbonisation, Fig. $18 b$ shows the same carbonised cork after physical activation, and Fig. $18 \mathrm{c}$ shows the chemical activation effect. ${ }^{152}$ The unusual chemical composition and microstructure of cork may lead to activated carbons with properties somewhat different from those obtained from other common precursors. Further extensive study on this point is clearly necessary.

\section{Pharmacological potential}

The biological activity of a molecular structure typically derives from metal ion chelators, proton precipitating agents and supporters of biological antioxidants. The biological activities of natural products are of strong current interest.

The pharmacological potential of cork lies in its low molecular weight components, but to date, only its friedelin and friedelin derivatives have been studied. ${ }^{157-}$ 160 Friedelin and related compounds extracted from other natural products have been studied ${ }^{76,78,157,161,162}$ and reported to show antioxidant, antistaminic, antiulcer, ${ }^{159}$ anti-inflammatory ${ }^{86}$ or even anticancer effects. ${ }^{80}$ Betulinic acid, a triterpene like friedelin has been studied ${ }^{163}$ for prevention and treatment of cancer and HIV infection. Separation and purification of these extracted compounds is problematic, since not all are important pharmaceutically.

Cork also contains sterols, flavonoids and simple phenolic compounds. The biological activity of these chemical families is well known. For example, sterols may reduce cholesterol problems ${ }^{164-166}$ or influence cancer proliferation. ${ }^{164,167}$ Flavonoids have been studied for their cancer chemoprevention ${ }^{168}$ and also their antioxidant activity. ${ }^{169,170}$

Currently, the antioxidant capacity of some cork components appears attractive and of interest to the food, cosmetic, plastics and pharmacological industries. 
They show potential in anticarcinogenic, antimutagenic, antiallergenic and antiaging applications. ${ }^{79}$ Antioxidants from natural products could be less expensive than synthetic variants. $^{79}$

\section{Cork powder}

Industrial transformation of cork generates up to $25 \mathrm{wt}-\%$ of cork dust as byproduct. ${ }^{143,171}$ This dust has been studied as a potential filler in hydroxypropyl cellulose (HPC), a cellulose derived, biodegradable and renewable material. ${ }^{171}$ Cork dust increased modulus and UTS, and decreased elongation of the pure HPC. The properties were optimal for a loading of $0.5 \%$, due probably to a better dispersion of the cork second phase. These results demonstrate that cork and HPC are energetically compatible. ${ }^{171}$ Another study consolidated cork dust by the application of heat and pressure. ${ }^{143}$ The consolidated material retains many of the properties of cork (thermal and fire resistance, chemical stability and low permeability) and presents improved mechanical properties and impermeability to water. The compressive modulus normal to the compaction direction reached $0 \cdot 76 \pm 0.02 \mathrm{GPa}$ (cf. values in Table 10); parallel to the compaction direction, the modulus was lower owing to bending in the cell walls during processing. The slow heat diffusion through the powder meant that thick samples were less well consolidated and had poorer properties than thin ones. As a result (and because of the gases originating from thermal decomposition), many cracks and fissures were seen. Consolidated cork dust may have interesting applications, since it bonds strongly to ceramic powders and pinewood and can compete with wood and polymers in price. ${ }^{143,172}$

\section{Ecoceramics}

Ecoceramics are receiving increasing attention. ${ }^{173}$ They can be fabricated using renewable resources (wood, cork) or waste materials (wood sawdust and cork dust), are hard and strong, have porous structure and low density, do not cause environmental pollution and are cheap to manufacture. ${ }^{174,175}$

Pyrolysis of wood is used to form a carbonaceous preform, a porous carbon material with a pipe-cell microstructure similar to that of the natural precursor. ${ }^{173}$ These structures are then infiltrated with oxides and non-oxides that react to form a strong ceramic or composite that can be used for applications including filters and catalyst supports, automotive components, tooling and wear components, porous ceramics for aerospace systems, absorbents, humidity and temperature sensors, heat insulating materials and electromagnetic shielding materials. ${ }^{175}$

Ecoceramics have been reported to show superior heat resistance, friction and wear resistance, corrosion resistance, damping properties, electrical properties and electromagnetic shielding ability. ${ }^{174,175}$ They have the benefits over traditional ceramics of lower processing temperature (lower energy consumption), a wide variety of microstructures that can be obtained using different types of wood or cork, and a low-cost starting material that has near-net and complex shape capabilities.

Most of the published work ${ }^{173-176}$ refers to wood as a precursor, but cork is a promising alternative. The structures and size of the pores in cork is dependent on source and pretreatment, and thus could be controlled to obtain ceramics with different morphologies and properties.

\section{Final remarks}

Cork has a remarkable combination of mechanical, chemical and morphological characteristics. This natural organic material continues to be widely used. It has evolved from simple, direct usage of the raw material, through products involving some industrial transformation to the point where it now represents a potential source material for high technology industries (pharmaceutical, ceramic, etc.).

This evolution has been supported and facilitated by the use of increasingly complex characterisation techniques that set the foundations for a realisation of the full potential of cork. From the initial microscopic observations of Hooke, cork has been the subject of diverse mechanical, physical, chemical and morphological characterisation, lately including thermally stimulated discharge current analysis, nuclear magnetic resonance and gas chromatography-mass spectroscopy.

Cork is resilient, strong (high specific strength), impervious to water, has a near zero Poisson coefficient, very low thermal conductivity, low density and a complex chemical structure. This combination of properties provides cork with characteristics hard to match with other materials: excellent sealing ability and ease of removal, thermal comfort and damping for walking, thermal insulation at very low temperatures, among others.

Cork has proved to be a highly adaptable material, giving rise to products of low and high incorporated technology. The continuing interest, the increasingly detailed characterisation and society's growing requirements for natural, renewable and sustainable raw materials will create novel market areas. In the research field, chemical characterisation and some physical properties still pose challenges and a significant contribution can be anticipated in areas of concern to the development of novel applications for cork and cork incorporating products.

\section{References}

1. L. Gil: 'Cortiça: produção, tecnologia e aplicação'; 1998, Lisbon, INETI.

2. A. Barberis; S. Dettori and M. R. Filiggheddu: J. Arid Environ., 2003, 54, 565-569.

3. H. Pereira: Boletim do Instituto dos Produtos Florestais - Cortiça, 1984, 545, 99-112.

4. C. Fialho, F. Lopes and H. Pereira: For. Ecol. Manage., 2001, 141, 251-258.

5. M. I. d. F. Carrasquinho: Boletim do Instituto dos Produtos Florestais - Cortiça, 1987, 583, 17-18

6. H. Pereira, M. E. Rosa and M. A. Fortes: IAWA Bull., 1987, 8(3), 213-217.

7. A. Costa, H. Pereira and A. Oliveira: For. Ecol. Manage., 2003, 175, 239-246.

8. M. Maâtaoui, H. Espagnac and N. Michaux-Ferriere: Ann. Bot., 1990, 66, 183-190.

9. B. Groh, C. Hubner and K. J. Lendzian: Planta, 2002, 215, 794 801.

10. H. Pereira: Boletim do Instituto dos Produtos Florestais - Cortiça, 1988, 600, 15-18.

11. M. F. S. Bento, H. Pereira, M. A. Cunha, A. M. C. Moutinho, K. J. v. d. Berg, J. J. Boon, O. v. d. Brink and R. M. A. Heeren: Holzforschung, 2001, 55(5), 487-493.

12. K. G. J. Nierop: J. Anal. Appl. Pyrol., 2001, 61, 111-132.

13. M. M. Caldas, J. L. Ferreira and M. Borges: Boletim do Instituto dos Produtos Florestais - Cortiça, 1986, 578, 339-342. 
14. J. R. Lawton: Bot. J. Linnean Soc., 1980, 80, 161-177.

15. H. Pereira: IAWA Bull., 1989, 10(2), 209-211.

16. M. L. Molinas and D. Verdaguer: Am. J. Bot., 1993, 80(2), 172181.

17. M. L. Molinas and D. Verdaguer: Am. J. Bot., 1993, 80(2), 182190.

18. F. Lopes and H. Pereira: Wood Sci. Technol., 2000, 34, 3-10.

19. M. Borges and C. Cunha: Boletim da Junta Nacional de Cortiça, 1985, 565, 678-679.

20. H. Pereira: Wood Sci. Technol., 1988, 22, 211-218.

21. F. Cumbre, F. Lopes and H. Pereira: Wood Fiber Sci., 2000, 32(1), $125-133$.

22. J. Graça, L. Barros and H. Pereira: Boletim da Junta Nacional de Cortiça, 1985, 566, 697-707.

23. A. M. Gil, M. Lopes, J. Rocha and C. P. Neto: Int. J. Biol. Macromol., 1997, 20, 293-305.

24. L. J. Gibson, K. E. Easterling and M. F. Ashby: Proc. R. Soc. Lond. A Mater., 1981, A377, 99-117.

25. H. Pereira and E. Ferreira: Mater. Sci. Eng., 1989, A111, 217-225.

26. L. J. Gibson: J. Biomech., 2005, 38, 377-399.

27. H. Pereira: Wood Sci. Technol., 1992, 26, 259-269.

28. L. J. Gibson and M. F. Ashby: 'Cellular solids: structure and properties', 2nd edn, 453-467; 1997, Cambridge, Cambridge University Press.

29. M. A. Fortes and M. E. Rosa: Boletim do Instituto dos Produtos Florestais - Cortiça, 1988, 593, 65-68.

30. A. P. M. Baptista and M. D. C. Vaz: Wear, 1993, 162, 990-995.

31. J. V. Natividade: 'Subericultura'; 1990, Lisbon, Ministério da Agricultura, Pescas e Alimentação.

32. N. M. A. Cordeiro, C. P. Neto, A. Gandini and M. N. Belgacem: J. Colloid Interf. Sci., 1995, 174, 246-249.

33. H. Pereira: Boletim do Instituto dos Produtos Florestais - Cortiça, 1984, 550, 237-240.

34. H. Pereira: Cortiça, 1979, 483, 259-264.

35. H. Pereira: Anais Instituto Superior Agronomia, 1981, 40, 17-25.

36. M. A. Bernards and N. G. Lewis: Phytochemistry, 1998, 47, 915 933.

37. M. F. S. Bento, M. A. Cunha, A. M. C. Moutinho, H. Pereira and M. A. Fortes: Int. J. Mass Spectrom., 1992, 112(2-3), 191-204.

38. P. J. Holloway: Chem. Phys. Lipids, 1972, 9, 171-179.

39. M. A. Bernards: Can. J. Bot., 2002, 80, 227-240.

40. J. Graça and H. Pereira: Biomacromolecules, 2000, 1(4), 519-522.

41. C. Quilchano and T. Marañón: Biol. Fertil. Soils, 2002, 35, 102107.

42. M. H. Lopes, C. P. Neto, A. S. Barros, D. Rutledge, I. Delgadillo and A. M. Gil: Biopolymers (Biospectroscopy), 2000, 57, 334-351.

43. M. H. Lopes, A. Sarychev, C. P. Neto and A. M. Gil: Solid State Nucl. Magn. Reson., 2000, 16, 109-121.

44. S. M. Rocha, B. J. Goodfellow, I. Delgadillo, C. P. Neto and A. M. Gil: Int. J. Biol. Macromol., 2001, 28, 107-119.

45. N. M. A. Cordeiro, M. N. Belgacem, A. J. D. Silvestre, C. P. Neto and A. Gandini: Int. J. Biol. Macromol., 1998, 22, 71-80.

46. N. M. A. Cordeiro, P. Aurenty, M. N. Belgacem, A. Gandini and C. P. Neto: J. Colloid Interf. Sci., 1997, 187, 498-508.

47. N. M. A. Cordeiro, N. M. Belgacem, A. Gandini and C. P. Neto: Bioresour. Technol., 1998, 63, 153-158.

48. E. Duran, L. Gorrichon, L. Cazaux and P. Tisnes: Tetrahedron Lett., 1984, 25, 2755-2758.

49. N. M. A. Cordeiro: 'Fraccionamento da cortiça e caracterização dos seus componentes. Estudo de possibilidades de valorização da suberina', Departamento de Química, Universidade de Aveiro, Aveiro, 1998

50. A. Asensio: Carbohydr. Res., 1987, 165, 134-138.

51. A. Asensio: Carbohydr. Res., 1987, 161, 167-170.

52. L. G. Akim, N. M. A. Cordeiro, C. P. Neto and A. Gandini: in 'Lignin: historical, biological, and materials perspectives', 291302; 2000, Washington, DC, American Chemical Society.

53. C. Amen-Chen, H. Pakdel and C. Roy: Bioresour. Technol., 2001, 79, 277-299.

54. M. H. Lopes, A. M. Gil, A. J. D. Silvestre and C. P. Neto: J. Agric. Food Chem., 2000, 48, 383-391.

55. J. C. Villar, A. Caperos and F. García-Ochoa: Wood Sci. Technol., 2001, 35, 245-255.

56. A. Asensio: Can. J. Chem., 1988, 66(3), 449-453.

57. A. V. Marques, H. Pereira, D. Meier and O. Faix: Holzforschung, 1994, 48 (Suppl.), 43-50.

58. R. Sun, J. M. Lawther and W. B. Banks: Ind. Crop Prod., 1998, 7, 121-128.

59. A. Oosterveld, J. S. Harmsen, A. G. J. Voragen and H. A. Schols: Carbohydr. Polym., 2003, 52, 285-296.
60. S. M. Rocha, M. A. Coimbra and I. Delgadillo: J. Agric. Food Chem., 2000, 48, 2003-2007.

61. S. Varea, M. C. García-Vallejo, E. Cadahía and B. F. d. Simón: Eur. Food Res. Technol, 2001, 213, 56-61.

62. E. W. Tegelaar, G. Hollman, P. Vandervegt, J. W. Deleeuw and P. J. Holloway: Org. Geochem., 1995, 23(3), 239-251.

63. J. E. O'Connell and P. F. Fox: Int. Dairy J., 2001, 11, 103-120.

64. J. W. LeFevre, K. I. McNeill and J. L. Moore: J. Chem. Educ., 2001, 78(4), 535-538.

65. S. M. d. R. S. Carriço: 'Estudo da composição química da estrutura celular e dos componentes voláteis da cortiça de Quercus suber L', Departamento de Química, Universidade de Aveiro, Aveiro, 1997.

66. E. Conde, E. Cadahía, M. C. García-Vallejo and J. R. GonzálezAdrados: J. Wood Chem. Technol., 1998, 18(4), 447-469.

67. J. M. David, F. A. Santos, M. L. d. S. Guedes and J. P. David: Quím. Nova, 2003, 26(4), 484-487.

68. G. Snakkers, G. Nepveu, E. Guilley and R. Cantagrel: Ann. For. Sci., 2000, 57, 251-260.

69. H. Pereira: Boletim do Instituto dos Produtos Florestais - Cortiça 1984, 550, 244-247.

70. N. Boudaoud and L. Eveleigh: J. Agric. Food Chem., 2003, 51, $1530-1533$.

71. S. Insa, V. Salvadó and E. Anticó: J. Chromatogr. A, 2004, 1047, $15-20$.

72. R. Juanola, L. Guerrero, D. Subirá, V. Salvador, S. Insa, J. A. Garcia Regueiro and E. Antico: Anal. Chim. Acta, 2004, 513, 291297.

73. V. Mazzoleni, P. Caldentey and A. Silva: Am. J. Enol. Viticult., 1988, 49(1), 6-10.

74. M. Riu, M. Mestres, O. Busto and J. Guasch: J. Chromatogr. A, 2002, 977, 1-8.

75. E. Conde, E. Cadahía, M. C. García-Vallejo, B. F. d. Simón and J. R. G. Adrados: J. Agric. Food Chem., 1997, 45, 2695-2700.

76. R. Llorach, J. C. Espín, F. A. Tomás-Barberán and F. Ferreres: J. Agric. Food Chem., 2003, 51, 2181-2187.

77. H. Pereira: Cortiça, 1981, 492, 57-59.

78. L. Gil and C. Moiteiro: in 'Ullmann encyclopedia of industrial chemistry', vol. 9, 503-522; 2002, Weinheim, Wiley-VCH.

79. A. Moure, J. M. Cruz, D. Franco, J. M. Domínguez, F. Sineiro, H. Domíngues, M. J. Núñez and J. C. Parajó: Food Chem., 2001, 72, 145-171.

80. V. Castola, B. Marongiu, A. Bighelli, C. Floris and J. Casanova: Ind. Crop Prod., 2005, 21, 65-69.

81. A. M. Miranda, A. S. R. Machado, H. Pereira and M. N. Ponte: in 'High pressure chemical engineering', (ed. P. R. van Rohr and E. Trapp), 417-422; 1996, Amsterdam, Elsevier.

82. M. K. Taylor, T. M. Young, C. E. Butzke and S. E. Ebeler: J. Agric. Food Chem., 2000, 48, 2208-2211.

83. A. M. S. R. Machado, M. N. D. Ponte, T. A. Casimiro and N. A. Ribeiro: 'Extraction of ceroid fraction of cork smoker wash solids with a supercritical fluid', EP1122259 A2, European Patent Office, Munich, 2001.

84. G. Lumia, C. Perre and J.-M. Aracil: 'Method for treating cork and extracting organic compounds from cork, with a dense fluid under pressure', EP1216123 B1, European Patent Office, Munich, 2000

85. E. J. Beckman: J. Supercrit. Fluid., 2004, 28, 121-191

86. B. Simándi, S. T. Kristo, Á. Kéry, L. K. Selmeczi, I. Kmecz and S. Kemény: J. Supercrit. Fluid., 2002, 23(2), 135-142.

87. A. Machado, R. Sardinha, E. deAzevedo and M. daPonte: J. Supercrit. Fluid., 1994, 7(2), 87-92.

88. M. Muin, A. Adachi, M. Inoue, T. Yoshimura and K. Tsunoda: J. Wood Sci., 2003, 49, 65-72.

89. M. Acda, J. Morrell and K. Levien: Wood Sci. Technol., 2001, 35(1-2), 127-136.

90. A. E. Hagerman: 'Tannin chemistry'; 2002, http://www.users. muohio.edu/hagermae/.

91. A. Peña-Neira, T. Hernández, M. C. García-Vallejo, E. Cadahia, B. F. d. Simón and J. A. Suarez: Am. J. Enol. Viticult., 1999, 50(3), 285-290.

92. R. F. Chandler and S. N. Hooper: Phytochemistry, 1979, 18, 711724.

93. V. V. Kane and R. Stevenson: J. Org. Chem., 1960, 25(8), 1394 1396.

94. V. Castola, A. Bighelli, S. Rezzi, G. Melloni, S. Gladiali, J.-M. Desjobert and J. Casanova: Ind. Crop Prod., 2002, 15, 15-22.

95. E. Conde, M. C. García-Vallejo and E. Cadahía: Wood Sci. Technol., 1999, 33, 271-283. 
96. E. Conde, M. C. Garcia-Vallejo and E. Cadahia: Wood Sci. Technol., 1999, 33, 229-244.

97. M. E. Rosa and M. A. Fortes: J. Mater. Sci., 1991, 26, 341-348

98. M. E. Rosa and M. A. Fortes: J. Mater. Sci., 1988, 23, 879-885.

99. A. Romano and M. A. Martins-Loução: Plant Cell Tissue Organ Cult., 1999, 59, 155-157.

100. M. A. Fortes and M. T. Nogueira: Mater. Sci. Eng., 1989, A122, 227-232.

101. M. A. Fortes: J. Phys. A - Math. Gen., 1995, 28, 1055-1068.

102. H. Pereira, J. Graça and C. Baptista: IAWA Bull., 1992, 13(4), 389-396.

103. H. Pereira: Revista Florestal, 1998, 2(XI), 46-50.

104. M. E. Rosa and M. A. Fortes: Mater. Sci. Eng., 1988, 100, 69-78.

105. M. E. Rosa and H. Pereira: Holzforschung, 1994, 48, 226-232.

106. M. C. Relvas: 'Cork boiling system consists of controlled water feed not impairing the physical and organoleptic properties of the product', PT102334, Instituto Nacional de Propriedade Industrial, Lisbon, 2002.

107. M. E. Rosa, H. Pereira and M. A. Fortes: Wood Fiber Sci., 1990, 22(2), 149-164.

108. C. M. C. P. Gomes, A. C. Fernandes and B. d. J. V. S. d. Almeida: J. Colloid Interf. Sci., 1993, 156(1), 195-201.

109. Anonymous: 'Process for producing, by dry means, pure expanded cork-bark agglomerate in the form of sheets coated with films and sheets of pure and black expanded cork-bark agglomerate with coating films', PT101993, Instituto Nacional de Propriedade Industrial, Lisbon, 1998.

110. J. F. Mano: J. Mater. Sci., 2002, 37, 257-263.

111. M. F. Vaz and M. A. Fortes: J. Mater. Sci., 1998, 33, 2087-2093.

112. J. F. Mano, N. T. Correia, J. J. M. Ramos and B. Saramago: J. Mater. Sci., 1995, 30, 2035-2041.

113. M. S. C. Dionísio, N. T. Correia, J. F. Mano, J. J. M. Ramos, A. C. Fernandes and B. Saramago: J. Mater. Sci., 1995, 30, 4394 4400.

114. J. N. Marat-Mendes and M. d. C. H. Lança: Jornada de Ciência e Tecnologia de Materiais 2004, 5, Sociedade Portuguesa de Materiais, Lisbon.

115. M. Malow and U. Krause: J. Loss Prevent. Proc., 2004, 17, 51-58.

116. D. Champion, M. Le Meste and D. Simatos: Trends Food Sci. Technol., 2000, 11, 41-55.

117. M. E. Rosa, M. A. Fortes and R. V. Nunez: Proc. 1st International Materials Symposium, Advanced Materials Forum I, April 2001, Coimbra, Portugal, 2002. Key Eng. Mater., 2002, 230-232, 295-299.

118. V. Dlust and F. Battistutta: 'Method to prepare cork for food purposes', EP1044773 A1, European Patent Office, Munich, 2000.

119. G. V. J. Luis: 'Method of decontaminating cork and making same more flexible and installation for performing said method', WO2004004995, World Intellectual Property Organization, Geneva, 2004

120. J. M. Valverde, J. F. D. Carrillo, E. S. Sinencio and R. P.-A. Valverde: 'Method for sorting cork stoppers', ES2140309, Oficina Española de Patentes y Marcas, Madrid, 2000.

121. H. Pereira, B. Melo and R. Pinto: Holz als Roh- und Werstoff, 1994, 51, 301-308.

122. R. J.-J. Puerto: 'Process for washing cork stoppers', FR2639282, Institut National de la Propriete Industrielle, Paris, 1990.

123. J. Jens: 'Treatment method for cork material and corks', CA2319351, Canadian Intellectual Property Office, Quebec, 1999.

124. J. Jens: 'Method for manufacturing sterilized corks involving microwave irradiation', NZ505790, Intellectual Property Office of New Zealand, Lower Hutt, 2002.

125. M. F. Cabral: 'Cork product treatment system and apparatuses by extraction of compounds dragged in water vapour', WO04014436A1, World Intellectual Property Organization, Geneva, 2004.

126. J. C. M. Bordado and J. P. S. Marques: 'New process for treating cork stoppers or planks for the reduction of strange aromas, namely 2,4,6-trichoroanisole', WO03041927A1, World Intellectual Property Organization, Geneva, 2003.

127. M. C. Díaz-Maroto, E. Sánchez-Palomo and M. S. Pérez-Coelho: J. Agric. Food Chem., 2004, 52, 6857-6861.

128. E. M. Díaz-Plaza, J. R. Reyero, F. Pardo, G. L. Alonzo and M. R Salinas: J. Agric. Food Chem., 2002, 50, 2622-2626.

129. A. Silva, M. Lambri and M. D. Faveri: Eur. Food Res. Technol., 2003, 216, 529-534.

130. A. Mas, J. Puig, N. Llado and F. Zamora: J. Food Sci., 2002, 67(4), 1374-1378

131. A. Díaz-Parralejo, M. A. Díaz-Díez, A. Macías-Garcia, P. RosaBlanco and V. G. Serrano: Mater. Lett., 2003, 57, 4004-4008.
132. E. Ferreira and H. Pereira: Cortiça, 1986, 576, 274-279.

133. R. Pinto and B. Melo: Boletim da Junta Nacional de Cortiça, 1988, 602, 322-328.

134. M. d. C. Proença: Boletim do Instituto dos Produtos Florestais Cortiça, 1984, 546, 139-147.

135. A. Tadeu and P. Santos: Appl. Acoust., 2003, 64, 287-310.

136. Anonymous: 'Process for the manufacture of a decorative product for walls or for floors, in the form of mosaic or plate, consisting of a coloured film of pigmented cork-bark- granulate agglomerate', PT100519, Instituto Nacional de Propriedade Industrial, Lisbon, 1994

137. A. Denisselle and G. Doubrovsky: 'Material in the form of a plate capable of forming a heat-insulating barrier, fire-protection wall including this material, and casing including such a wall', FR2672961, Institut National de la Propriete Industrielle, Paris, 1992.

138. B. Christian: 'Shoe sole', EP1314370, European Patent Office, Munich, 2003.

139. I. Hajime: 'Wear-resistant flooring', JP2001047411, Japan Patent Office, Tokyo, 2001.

140. M. Takayuki, T. Nobuhiro, K. Akio and S. Minoru: 'Water pressure resisting sound insulator', JP9198050, Japan Patent Office, Tokyo, 1997.

141. A. Hiroaki: 'Gasket material layer including cork, fibers, rubber, and a rubber chemical', US5615897, United States Department of Commerce: Patent and Trademark Office, Arlington, VA, 1997.

142. P. E. Duchemin and R. A. L. L. Touche: 'Cork-based improved thermal insulating material and process for obtaining it', FR2626519, Institut National de la Propriete Industrielle, Paris, 1989.

143. L. M. d. C. C. Gil: Biomass Bioenerg., 1997, 13(1-2), 59-61

144. N. Chubar, J. R. Carvalho and M. J. N. Correia: Colloid. Surface. A, 2004, 238, 51-58.

145. N. Chubar, J. R. Carvalho and M. J. N. Correia: Colloid. Surface. A, 2004, 230, 57-65.

146. I. Villaescusa, M. Martínez and N. Miralles: J. Chem. Technol. Biotechnol., 2000, 75, 812-816.

147. F. Pagnanelli, F. Vegliò and L. Toro: Chemosphere, 2004, 54, 905 915.

148. B. Volesky: Hydrometallurgy, 2001, 59, 203-216.

149. R. Machado, J. R. Carvalho and M. J. N. Correia: J. Chem. Technol. Biotechnol., 2002, 77(12), 1340-1348.

150. N. Fiol, I. Villaescusa, M. Martínez, N. Miralles, J. Poch and J. Serarols: Environ. Chem. Lett., 2003, 1, 135-139.

151. S. Acevedo, M. A. Ranaudo, G. Escobar, L. Gutiérrez and P. Ortega: Fuel, 1995, 74, 595-598.

152. P. J. M. Carrott, M. M. L. R. Carrott and R. P. Lima: Carbon, 1999, 37, 515-517.

153. A. P. Carvalho, B. Cardoso, J. Pires and M. B. d. Carvalho: Carbon, 2003, 41, 2873-2884.

154. A. P. Carvalho, M. Gomes, A. S. Mestre, J. Pires and M. B. d. Carvalho: Carbon, 2004, 42, 667-691.

155. J. Hanzlík, J. Jehlicka, O. Sebek, Z. Weishauptová and V. Machovic: Water Res., 2004, 38, 2178-2184.

156. P. J. M. Carrott, M. M. L. R. Carrott, P. A. M. Mourão and R. P. Lima: Adsorp. Sci. Technol., 2003, 21(7), 669-682.

157. C. L. Queiroga, G. F. Silva, P. C. Dias, A. Possenti and J. E. d. Carvalho: J. Ethnopharmacol., 2000, 72, 465-468.

158. A. C. Nossack, E. C. d. Vasconcelos, J. H. Y. Vilegas, F. M. Lanças and N. F. Roque: Phytochem. Anal., 2000, 11, 243-246.

159. C. Moiteiro, F. Justino, R. Tavares, M. J. Marcelo-Curto and M. H. Florencio: J. Nat. Prod., 2001, 64, 1273-1277.

160. C. Moiteiro, C. Manta, F. Justino, R. Tavares, M. J. M. Curto, M. Pedro, M. S. J. Nascimento and M. Pinto: J. Nat. Prod., 2004, 67(7), 1193-1196.

161. H. Duan, Y. Takaishi, H. Momota and Y. Ohmoto: Tetrahedron, 2001, 57, 8413-8424.

162. P. Geissberger and U. Séquin: Acta Trop., 1991, 48, 251-261.

163. R. H. Cichewicz and S. A. Kouzi: Med. Res. Rev., 2004, 24(1), 90 114.

164. A. B. Awad, H. Williams and C. S. Fink: J. Nutr. Biochem., 2003, 14, 111-119.

165. I. Ikeda and M. Sugano: Biochim. Biophys. Acta, 1983, 732, 651658.

166. H. Tapiero, D. M. Townsend and K. D. Tew: Biomed. Pharmacother., 2003, 57, 321-325.

167. S. Block, C. Baccelli, B. Tinant, L. V. Meervelt, R. Rozenberg, J.-L. H. Jiwan, G. Llabrès, M.-C. D. Pauw-Gillet and J. QuetinLeclercq: Phytochemistry, 2004, 65, 1165-1171. 
168. Q. Cai, R. O. Rahn and R. Zhang: Cancer Lett., 1997, 119, 99107.

169. Y. Hanasaki, S. Ogawa and S. Fukui: Free Radic. Biol. Med., 1994, 16(6), 845-850.

170. C. A. Rice-Evans, N. J. Miller and G. Paganga: Free Radic. Biol. Med., 1996, 20(7), 933-956.

171. M. H. Godinho, A. F. Martins, M. N. Belgacem, L. M. d. C. C. Gil and N. M. A. Cordeiro: Macromol. Symp., 2001, 169, 223228.

172. J. Diez, J. L. Manjon, G. M. Kovacs, C. Celestino and M. Toribio: Appl. Soil Ecol., 2000, 15(2), 119-123.
173. M. Singh and B.-M. Yee: J. Eur. Ceram. Soc., 2004, 24, 209-217.

174. D. Zhang, X.-q. Xie, T.-x. Fan, B.-h. Sun, T. Sakata, H. Mori and T. Okabe: Mater. Sci. Eng., 2003, A351, 109-116.

175. M. Singh, J. Martínez-Fernández and A. R. d. Arellano-López: Curr. Opin. Solid State Mater. Sci., 2003, 7, 247-254.

176. J. Qian, Z. Jin and J. Wang: Mater. Sci. Eng., 2004, A368(1-2), 71-79.

177. H. Medeiros: Boletim da Junta Nacional de Cortiça, 1945, 76, 165 170 .

178. P. Sitte: Protoplasma, 1962, 54(4), 555-559.

179. P. Kolattukudy: Science, 1980, 208(4447), 990-1000. 